\title{
Geleneksel Kastamonu Konut Mimarisinin Cumhuriyet Dönemi Sivil Mimarisine Yansımaları
}

\section{Dr. Öğr. Üyesi Bülent Oral ${ }^{1 *}$ Cüneyt Özden ${ }^{2}$}

Geliș tarihi: 22.02 .2020

Kabul tarihi: 25.03 .2020

\section{Atıf bilgisi:}

IBAD Sosyal Bilimler Dergisi

Sayı: $7 \quad$ Sayfa: $306-328$

Yıl: 2020 Dönem: Yaz

This article was checked by Turnitin. Similarity Index 1\%

Bu makalede araştırma ve yayın etiğine uyulmuştur.

1 Karabük Üniversitesi, Türkiye, bulentoral7@gmail.com, ORCID ID: 0000-0003-1247-4679

2 Karabük Üniversitesi, Türkiye, cuneytozden@outlook.com,

ORCID ID: 0000-0003-0101-6904.

* Sorumlu yazar öz

Bu çalışmada Kastamonu'daki geleneksel mimari üslubun günümüzde inşa edilmiş modern yapılara etkisini örnek yapılar üzerinden ortaya koymak amaç edinilmiștir. Böylece günümüz Kastamonu kentinde mimari tarzı şekillendiren unsurlar, bu unsurların nedenleri ve bunların modern mimariye etkileri birlikte açıklanmıştır. Geleneksel dokunun, kent merkezinde Hisarard1, Cebrail, Akmescit, Honsanlar, Atabeygazi, İsmailbey, Topçuoğlu ve İsfendiyar mahalleleri ve bu yerlere yakın bölgelerde yoğunlaştığı görülmektedir. Kastamonu'da kentsel sit alanlarının bulunması ve Kastamonu Belediyesi'nin 2015-2019 yılları arasındaki sokak iyileştirme çalışmaları ile birlikte modern yapılarda da geleneksel dokuya öykünülerek inşa edilen yapılarda nicel olarak artış göstermiştir. Kentte geleneksel dokuya öykünme çabaları; konaklar, apartmanlar, siteler, villa tipi evler vb. konutların yanı sıra kamu kurumları ile özerk ve yarı özerk kurumlar tarafından inşa ettirilen hizmet binaları, ticaret yapıları, park, bahçe, meydan ve refüjlerdeki simgesel peyzaj düzenlemelerinde inşa edilen işlevsel ve dekoratif yapılarda görülür.

Anahtar Kelimeler: Kastamonu, Mimari, Modern, Geleneksel, Sivil, Konut 


\title{
Reflections of Traditional Kastamonu Architecture on Republican Period Civil Architecture
}

\author{
Assist. Prof. Dr. Bülent Oral ${ }^{1 *}$ \\ Cüneyt Özden ${ }^{2}$
}

First received: 22.02 .2020

Accepted: 25.03.2020

\section{Citation:}

IBAD Journal of Social Sciences

Issue: 7

Year: 2020

\author{
Pages: $306-328$
}

Session: Summer

This article was checked by Turnitin. Similarity Index $1 \%$

1 Universitiy of Karabuk, Turkey, bulentoral7@gmail.com,

ORCID ID: 0000-0003-1247-4679.

2 Universitiy of Karabuk, Turkey, cuneytozden@outlook.com,

ORCID ID: 0000-0003-0101-6904.

* Corresponding Author

\begin{abstract}
In this study, it is intended to show how traditional Kastamonu architecture shaped neighbourhood textures by affecting today's civil architecture through sample constructions. Therefore, the aspects, present day Kastamonu city architecture style, reasons of these aspects and how these, affect modern architecture are explained altogether. It is seen that traditional patterns center in Hisarardi, Cebrail, Akmescit, Honsanlar, Atabeygazi, Ismailbey, Topcuoglu and Isfendiyar districts and in other districts close to those. Kastamonu Municipality's street reconstruction works between 2015-2019 and presence of city site areas caused diversity in modern architecture of the city. Imitation to traditional pattern in the city, seems in mansions, apartments, sites, villa style houses, public institutions, commercial structures built by self-reliant and semi-self- reliant institutions alongwith park, garden, avenue and in functional decorative structures on figurative landscapes. Aside from residences, in structures built by self-reliant and semi-self-reliant institutions, imitation to historical patterns is pretty strong. In public structures in site areas, characteristics of houses that have city's historical pattern seem only on the frontispieces through their linear features and traditional morphologies whilst this effect is weak in public structures outside of the site area.
\end{abstract}

Keywords: Kastamonu, Architecture, Modern, Traditional, Civil, House 


\section{I.GİRIŞ}

Tarihin farklı dönemlerinde geçmişe öykünülerek inşa edilmiş mimari yapılarla karşılaşmak mümkündür. Örneğin Roma şehirleri olan Pompei ve Herculaneum'da yapılan arkeolojik kazılar, Roma mimarisine karşı bir ilgi doğurmuştur (Frampton, 2007, s.12-13). Neoklasizm olarak tanımlanan bu dönemde, Antik Çağ ve bununla ilişkili olarak Rönesans'a çizgisel üslup ve anlayışla bağlı yapılar inşa edilmiştir (Oral, 2019, s.597). Siyasi olarak desteklenen bu durum, süreç içinde Osmanlı toprakları içinde de görülen bir mimari anlayış doğurmuştur (Özlü, 2015, s.295-321). Türk sanatında ise I.ve II. Ulusal Mimarlık dönemlerinde Selçuklu ve Osmanlı mimarisinde görülen bazı öğelerin yapıların cephelerinde ve iç mekânlarında uygulandığı bilinmektedir (Aslanoğlu, 1980). Ankara, İstanbul ve İzmir başta olmak üzere ülke çapında bu mimarlık anlayışının yansımaları görülmüştür. Bu dönemin mimarlık anlayışını belirleyen unsurların siyasal gelişmeler ile ilişkisini ortaya koyan yapılara Ankara'da inşa edilen 1924-1960 yılları arasında II. TBMM Binası olarak kullanılan yapı iyi bir örnek oluşturmaktadır. Ayrıca I. Ulusal Mimarlık Akımı anlayışının henüz biçimsel olarak kimlik kazanmadığı dönemde yapılmasına karşın; Osmanlı Klasik mimarlık yaklaşımlarının bir kısmının seçmeci anlayışta uygulandığı Vedat Tek tarafindan yaptırılan Kastamonu Hükümet Konağı -bu makale konusunun geçtiği kentte olması bakımından- ayrıca dikkat çekicidir.

Günümüz Kastamonu'sunda modern yap1 malzemeleri ile inşa edilen yapılarda Kastamonu'nun geleneksel mimarisine öykünüldüğü gözlenmektedir. Avrupa'da kültür varlıklarının korunması bilincinin yaygınlaşması, ülkemizde de bu alanda adımların atılmasına olumlu katkı sağlamışıtır. Koruma bilincinin özellikle sivil alandaki mimari eserler üzerinde yaygınlaşması dikkat çekicidir. Kastamonu'daki tarihi dokunun günümüzde güçlü bir şekilde görülmesi 19. yüzyılda çeşitli tarihi kentlerdeki mimari yapılarda gerçekleştirilen onarımlar ve paralelinde inşa edilen tarihi evlerde görülür. (Çolpan ve Biçer, 2002, s.64; Oral, 2019, s.625). Bu bağlamda Kastamonu'da koruma tedbirleri alınmış il geneline yayılan 1177 adet tarihi ev ve konak bulunmaktadır (Yeter, 2002, s.79).

Kastamonu'nun kültür varlığı olarak koruma altına alınan mimari eserlerinin büyük bir kısmı kentsel sit alanı içinde bulunmaktadır. Sit alanı içinde Osmanlı konut mimarisinin özelliklerini bir bütün olarak yansıtan konak ve evler günümüz kentinin konut dokusunu büyük ölçüde etkileyen bir unsur haline gelmiştir. Kentin yerleşim planı incelendiğinde iki farklı yerleşim türünün ortaya çıktığı gözlenmektedir. Sit alanı içinde ve sit alanı dışında olmak üzere iki başlıkta irdeleyeceğimiz yerleşim planı günümüzde kentin imar planını belirleyen bir durum haline gelirken, sit alanı olarak tescillenen bölgede modern yapı malzemeleri kullanılarak çok katlı apartmanların yoğun bir şekilde inşa edildikleri gözlenmektedir. Tarihi Kastamonu'da, kent dokusunun merkezine inşa edilen çok katlı apartmanların varlığı koruma tedbirlerinin geç başlatılmasının dramatik bir sonucudur. Kentin yeni yerleşim dokusu içinde ise toplu konutların, çok katlı apartmanların ve sitelerin geniş alanlara yayılarak inşa edildikleri görülmektedir (Harita.1). 


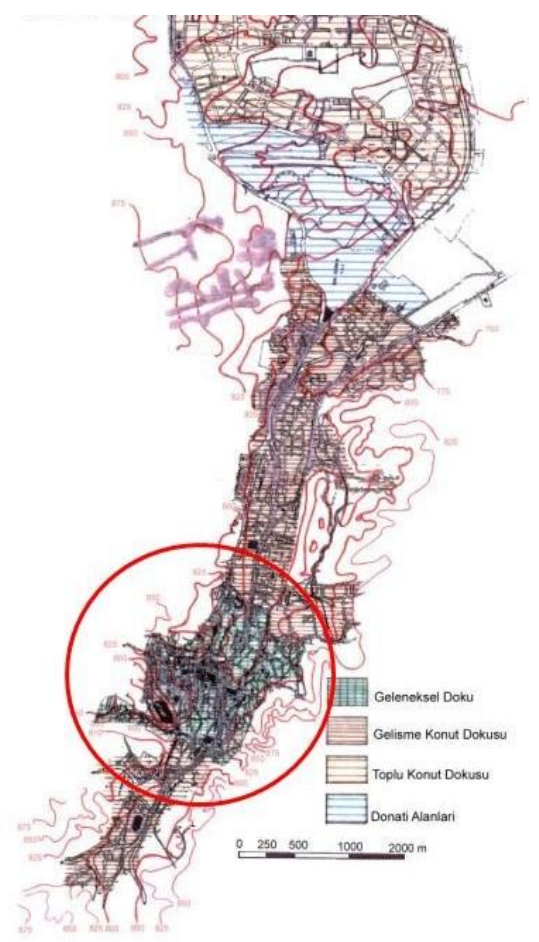

Harita 1. Kastamonu kentinin yerleşim planı (Çolpan ve Biçer, 2002, s.64).

Kent merkezinde tarihi Osmanlı konut mimarisinin bulunduğu Akmescit, Atabeygazi, Cebrail, Hisarardı, Honsanlar ve İsmailbey mahalleleri kentin sit alanı içinde bulunurken; geleneksel mimariye öykünmenin görüldüğü mahalleler ise Kuzeykent ve Olukbaşı çevresi olmuştur. Modern yapı malzemeleri ile inşa edilen sit alanlarındaki yapılarda geleneksel doku, yapıların cephelerinde yoğun bir şekilde gözlemlenmektedir. Buna karşın yapıların iç mekânlarda geleneksel öykünme zayıftır. Cephelerdeki etki, renk dokusu ve bazı geleneksel biçimlerle belirginleşirken iç mekânlarda az sayıda olsa da ahşap tavanların kullanımına devam edildiği görülür. Kentin yeni yerleşim yerlerinde de tarihi Kastamonu evlerine öykünüldüğü görülmektedir. Kastamonu'da geleneksel mimariye öykünme; konaklar, evler, apartmanlar, siteler, villa tipi evler, kamu kurumları ile yarı özerk ve özerk kurumlar tarafından inşa ettirilen yapılar ve ticaret yapılarında görülmektedir. Ayrıca kenti simgeleyen park, bahçe ve meydanlarda da geleneksel dokuya öykünerek oluşturulan dekoratif öğeler bulunmaktadır.

Bu makalede, araştırma sürecinde elde edilen buluntular çerçevesinde Kastamonu'nun geleneksel konut mimarisinin günümüzde inşa edilmiş yapılara etkileri, bu etkinin nasıl geliştiği, hangi nedenlere bağlı olduğunun belirlenmesi amaçlanmıştır.

\section{II.KASTAMONU'NUN KONUMU VE KISA TARİHÇESİ}

Kastamonu, kuzeyinde Karadeniz, güneyinde Ilgaz Dağları ile çevrili Batı Karadeniz bölgesinin yüzölçümü bakımından en büyük ilidir. Tarihte belgelerde Paflagonya olarak tanımlanan bölge içinde yer alan Kastamonu'da birçok medeniyete ait izlere rastlanmaktadır (Gökoğlu, 1952, s.24). En eski bilgilerin Hitit tabletlerinde bulunduğu kent, Paflagonyalılar olarak bilinen kavimden sonra Romalıların eline geçmiştir (İbret, 2004, s.161-162). Roma'nın ikiye ayrılması ile kent Bizans İmparatorluğunun (Doğu Roma) kontrolünde kalmıştır (Eyüpgiller, 1999, s.53). 1084 y1lından sonra bölgenin Danişmetlilerin eline geçmesi ile kentte Türk hakimiyeti süreci başlamıştır (Kankal, 2004, s.1). 12. yüzyıl sonlarında Çobanoğullarının eline geçen kentte, imar faaliyetleri de hız kazanmıştır (Şahin, 2001, s.585). 14. yüzyılda ise Candaroğullarının hâkimiyetine geçen kentte bu dönemdeki iskân hareketlerinin Osmanlı Devleti'nden önce en yoğun olduğu dönem olduğu kabul edilmektedir. Kent Osmanlı Devleti'nde sancak olmuştur (Uzunçarş111, 1988, s.91). Kastamonu Sancağı Bolu, Çankırı, Sinop, Safranbolu gibi yerleşim yerlerini kapsamıştır. Böylece kentin nüfusunda önemli artışlar görülmüştür (İbret, 2004, s.164). Tarih boyunca önemli bir yerleşim yeri olan Kastamonu, Cumhuriyet Döneminde de 
önemini korumuştur. Kentteki imar faaliyetleri günümüzde kentin dokusunun ve yerleşim planının yeniden şekillenmesine neden olmuştur.

\section{III.GELENEKSEL KASTAMONU EVLERİNIN GENEL ÖZELLİKLERİ}

Anadolu'da kimliğini kazanan ve Balkanlar'a kadar yayılan Türk ev geleneğinin biçimi Kastamonu kentinde de görülmektedir (Eldem, 1984, s.24). Günay, Türk ev geleneği adlı çalışmasında Kastamonu evlerini, Safranbolu, Sinop, Mudurnu ve Amasya evleri ile birlikte Kuzey Anadolu evleri olarak gruplandırmıştır (Günay, 1988, s.19-23). Bu bölgelerde bulunan evler 18. yüzyıla kadar açık sofalı olarak görülürken bu devirden sonra sofa iç ve ortaya doğru şekillenmiştir (Eldem, 1984, s.27-28). Evlerde taşıyıcı sistemi ahşap çatkı olup içi kerpiç, taş ve tuğlalarla doldurulmuştur. Evler daha çok iki katlı ve üç katlı olarak karşımıza çıkmaktadırlar (Eyüpgiller, 1999, s.237-245). Kastamonu evlerinin plan şemasını da belirleyen unsur sofa olmuştur. Sofaya bağlı bir şekilde tasarlanan evler iki farklı biçimde görülürler. Birincisi sofa açık havanın koşullarına uyum sağlayabilecek şekilde yapılaması (çardaklı konutlar), ikincisi ise kapalı havaların koşulları için yapılan iç sofalı evler görülmektedirler. Kastamonu evlerinin cephe özellikleri içinde ise çatı odaları, pencereler, çıkmalar ve beyaz renk üzerine zıtlık oluşturan koyu kahverengi ahşaplar dikkat çekmektedir. Çatı odaları ise evin bütününden bağımsız olarak yapılan ve kendisine ait başka bir çatısı olan odalar ile evin çatı eğimi içinde yer alan odalar olarak iki faklı şekilde görülmektedirler (Eyüpgiller, 1999, s.240-255).

\section{IV.GELENEKSEL MIMARININ YENI YAPILAN KONUTLAR ÜZERINDEKI ETKISI}

Konut mimarisi insanların, yalnızca gündelik yaşamlarını sürdürdükleri bir yaşam alanı değil; aynı zamanda sosyal, ekonomik durumları ile estetik anlayışlarının bir yansımasıdır. Konutlar toplumun mimaride ulaştığı seviye ve toplumsal yaşam ve anlayışın bir yansıması olmuştur. Kastamonu'da da tüm bu yönleriyle birlikte geleneksel mimariden etkilenen apartmanlar, villa tipi evler, çok katlı siteler, kamu yapıları, yarı özerk ve özerk kurumlar tarafindan inşa ettirilen yapılar, ticaret yapıları ve dekoratif ögeler (çöp kutusu, kuş evi, sokak kütüphanesi) bu başlık altında incelenmiştir.

\section{IV.I.Geleneksel Mimariden Etkilenen Apartmanlar}

Modernleşme ile betonarme karkas, malzeme ve teknik açıdan ortaya çıkan gelişmeler yüksek katlı evlerin yapılması kolaylaşmıştır. Buna bağlı olarak ortaya çıkan apartmanlar, birden fazla ailenin barınma ihtiyacını gideren konut türlerinde başı çeker. Kastamonu kentinde tarihi dokudan etkilenerek inşa edilen apartmanların cephelerinde yörenin geleneksel mimarisine uygun özellikler görülmektedir. Kentte geleneksel mimariden öykünülerek yapılan apartmanlar şunlardır; Hatice Topaloğlu Apartmanı (2000), İlhan Sağlar Apartmanı (2005), Ahmet Yahyaoğlu Apartmanı (2018), Keskin Apartmanı (2005), Kırıkoğlu Apartmanı (2005), Zincirlioğlu Apartmanı (2017), Alikamanoğlu Apartmanı (2019), Gölpark Kuzeykale Apartmanı (2018), Egemen Apartmanı (2018) ve Safran Apartmanı (2017)'dır.

Hatice Topaloğlu apartmanı kentin birinci derece sit alanı olarak belirlenen bölgesinde Şeyh Şaban-1 Veli caddesinde yer almaktadır. Sit alanı içinde olması nedeniyle tarihi dokuya özellikle yapının cephelerinde bağlı kalındığı görülür. Üç katlı olarak inşa edilen apartmanın zemin katı dükkân olarak kullanılmaktadır. Zemin dışındaki diğer katlarda beyaz kireç üzerine uygulanan yatay ve dikey ahşap şeritler, üçgen alınlığa sahip orta cephe ve üçgen alınlığa sahip pencere biçimleri Kastamonu'daki geleneksel konakların yansımalarıdır. Yapının çatısı ise betonarme olup üzeri ahşap ile kaplanmıştır. Yapının iç mekânında ise geleneksel mimariye öykünme yoktur (Foto.1) 


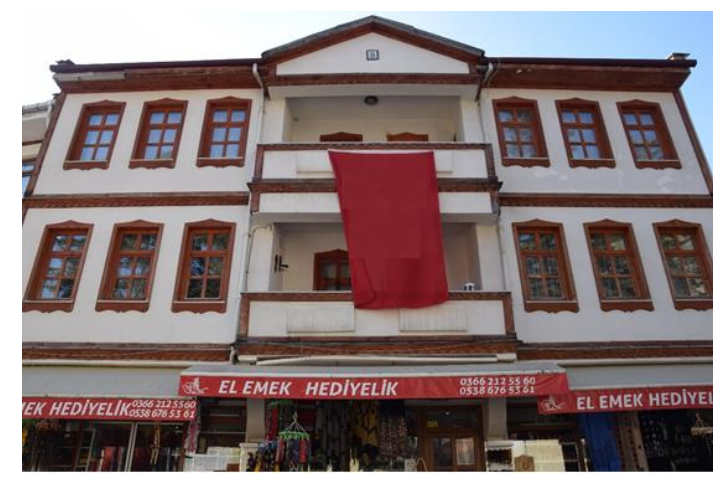

Foto 1. Hatice Topaloğlu Apartmanı, 2000

Hatice Topaloğlu apartmanı bitişiğinde bulunan İlhan Sağlar apartmanı da benzer bir düşünce ile ele alınmıştır. Üç katlı olan yapının zemin katı dükkân olarak kullanılırken diğer katlar ailelerin barınma ihtiyacını gideren dairelere bölünmüşlerdir. Betonarme malzemenin kullanıldığı yapının katları arasında görülen yatay şeritlerde ahşap malzeme yerine boya kullanılırken geleneksel mimaride görülen ahşap şeritlerin modern bir yaklaşımla ele alındığı görülmektedir. Yalın ve sade dikdörtgen pencerelerde modern bir anlayış görülse de yan yana üçlü pencere düzeni Kastamonu konut mimarisinin pencere düzenine öykünme içerir (Foto.2)

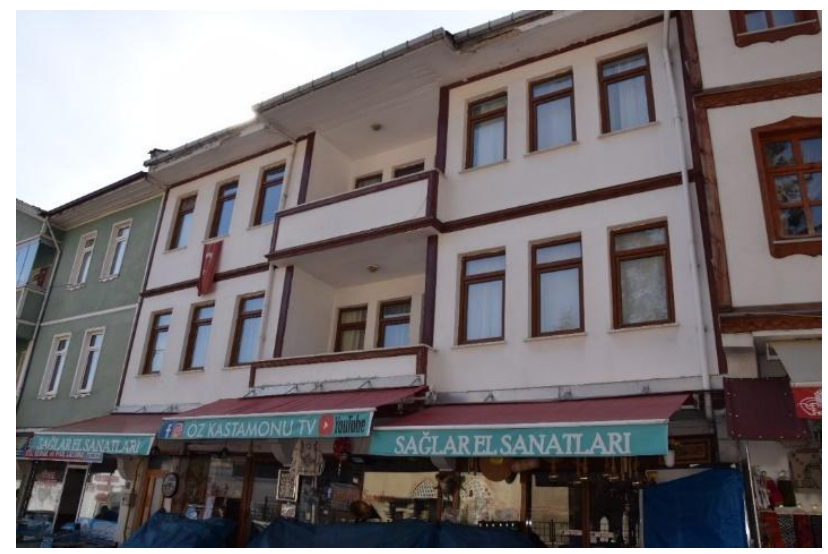

Foto 2. İlhan Sağlar Apartmanı, 2005

Aynı cadde üzerinde 2018 yılında inşa edilmiş olan Ahmet Yahyaoğlu apartmanında da geleneksel mimariye öykünüldüğg̈ görülmektedir. Üç katlı olarak inşa edilen yapının zemin katının bir bölümü dükkân olarak kullanılmaktadır. İlhan Sağlar apartmanı ile benzer bir renk dokusuna sahip olan Ahmet Yahyaoğlu apartmanında geleneksel izlerin daha yoğun bir şekilde görüldüğü gözlenmektedir. Özellikle ikinci kattan başlayarak üçüncü kat boyunca yükselen ve üçgen alınlıkla son bulan orta çıkma, geleneksel biçimlerin betonarme yapılarda varlığını gösterirken; katlar arasındaki şeritler, pencere biçimleri ve renk uyumu tarihi Kastamonu evlerinin bir yansımasıdır. Geniş saçaklı betonarme çatısında ise malzeme farklılığı olsa da biçimsel olarak geleneksel bir yaklaşıma bağlllık göze çarpar (Foto.3). 


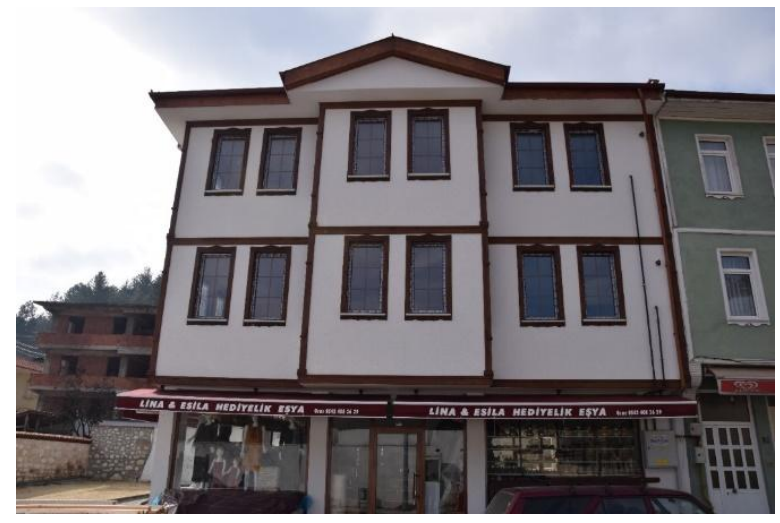

Foto 3. Ahmet Yahyaoğlu Apartmanı, 2018

Kentin sit alanı içinde bulunan ve geleneksel mimarinin özelliklerini yoğun bir biçimde yansıtan yapılardan birisi ise Cebrail mahallesinde görülen Keskin apartmanıdır. Apartman 2005 yılında aynı parselde yıkık bir şekilde bulunan tarihi bir yapının yerine Ankara Kültür ve Tabiat Varlıklarını Koruma Kurulu onayıyla inşa edilmiştir. ${ }^{1}$ Üç katlı yapının zemin katı dükkân olarak kullanılmaktadır. 'L' planı şeklinde yolun biçimine göre tasarlanan yapının her iki cephesinde de üçüncü katın ortasında ahşap destekler üzerine oturan birer orta çıkma bulunmaktadır. Bu çıkma ve ahşap çerçeveli dikdörtgen pencereler geleneksel konut mimarisinin bir yansımasıdır. Yapının cephelerinde ve cephelerin kesişen noktalarındaki yatay/dikey yönde uzayan ahşap şeritlerle bir bütünlük oluşturan renk dokusu ile kiremit kaplı kırma çatısında güçlü bir geleneksel mimariye öykünme görülür (Foto.4) Yapının iç mekânına hâkim anlayış tamamen moderndir.

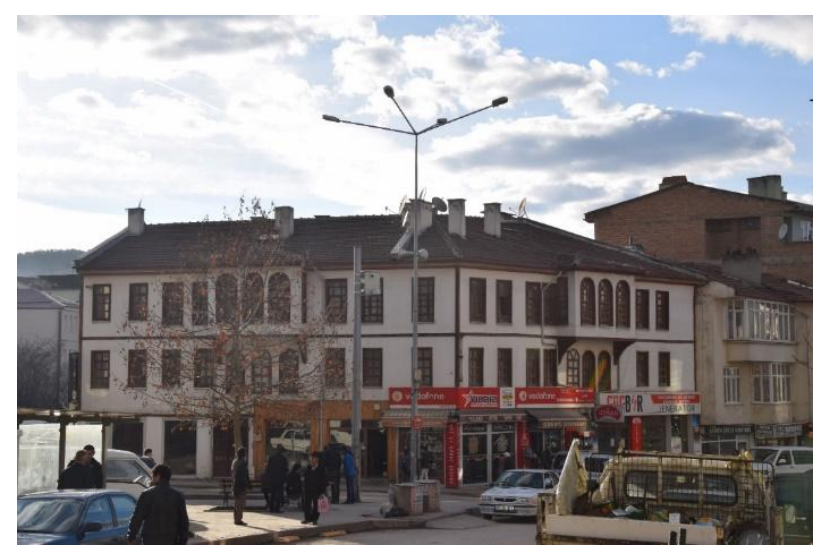

Foto 4. Keskin Apartmanı, 2005

Keskin apartmanının ana arterlere bakan cephelerinde vurgulanan geleneksel doku, diğer cephelere taşınmamıştır. Bu cepheler sıvanmayarak yapı malzemeleri açıkta bırakılmıştır. Geleneksel dokuya ekonomik yeterlilik ölçüsünde bağlı kalındığını göstermesi bakımından bu durum önemlidir (Foto.5).

\footnotetext{
1 Aynı dönemde ve aynı sebeplerle yeniden inşa edilen Kırıkoğlu Apartmanının sahibi Ahmet Kırık ile yapılan röportaj, 10.03.2019.
} 


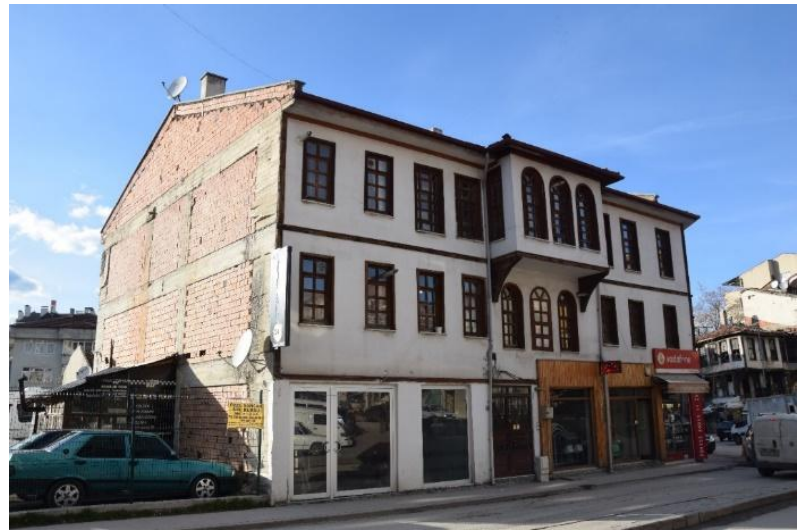

Foto 5. Keskin Apartmanı, tuğla ile örülen yan cephe detayı

Keskin apartmanında görülen mimari uygulamalar ve yaklaşım biçimlerinin bir benzeri de Kırıkoğlu apartmanında görülür. Yapı betonarme karkas malzemeden yapılmış olup üç katlıdır. Yapının zemin katı ticaret amaçlı kullanılmaktadır. Yapının ön cephesindeki yatay ve dikey şeritler, ahşap çerçeveli pencereler ve geniş saçaklı çatı geleneksel mimarinin birer yansımalarıdır (Foto.6)

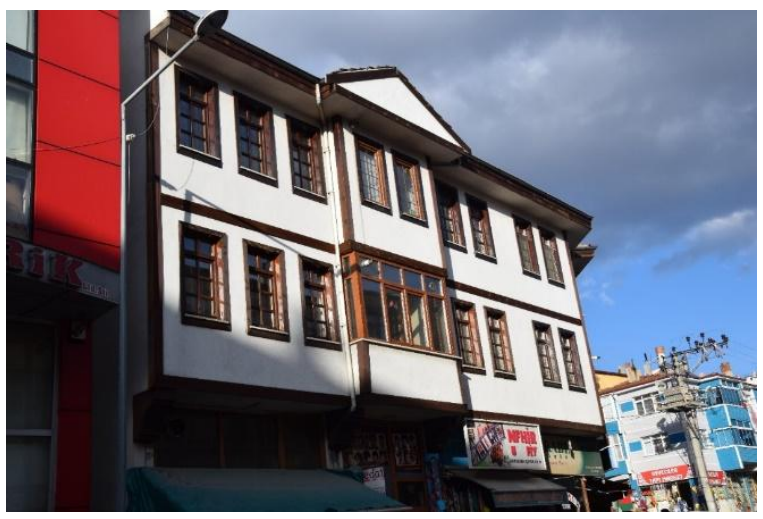

Foto 6. Kırıkoğlu Apartmanı, 2005

Keskin apartmanında yalnızca ön cephelerde yoğunlaşan geleneksel yaklaşım, benzer amaçla inşa edilen Kırıkoğlu apartmanının tüm cephelerinde uygulanmıştır. Özellikle arka cephedeki ikili ve üçlü pencere düzeni ve ahşap çerçeveler geleneksel konut mimarisinin birer yansımasıdır (Foto.7). Apartmanın içinde ise geleneksel mimariye öykünme yoktur.

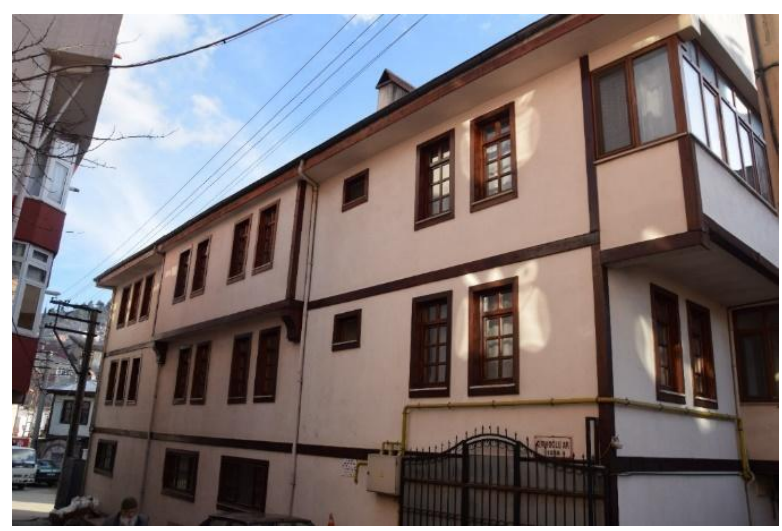

Foto 7. Kırıkoğlu Apartmanı, arka cephesi

Betonarme karkas malzeme ile inşa edilen Zincirlioğlu apartmanı da Keskin apartmanı ve Kırıkoğlu apartmanının bulunduğu cadde üzerinde yer almaktadır. Ancak bu yapıdaki geleneksel yaklaşım diğer iki yapıya göre daha zayıftır. Dört katlı olarak inşa edilen Zincirlioğlu apartmanının zemin katı dükkânlara 
ayrılmıştır. 'L' biçiminde tasarlanan yapının geniş saçaklı çatısı ile ahşap çerçevelere sahip yalın dikdörtgen pencereleri cephelerdeki geleneksel yaklaşımı yansıtmaktadır (Foto.8).

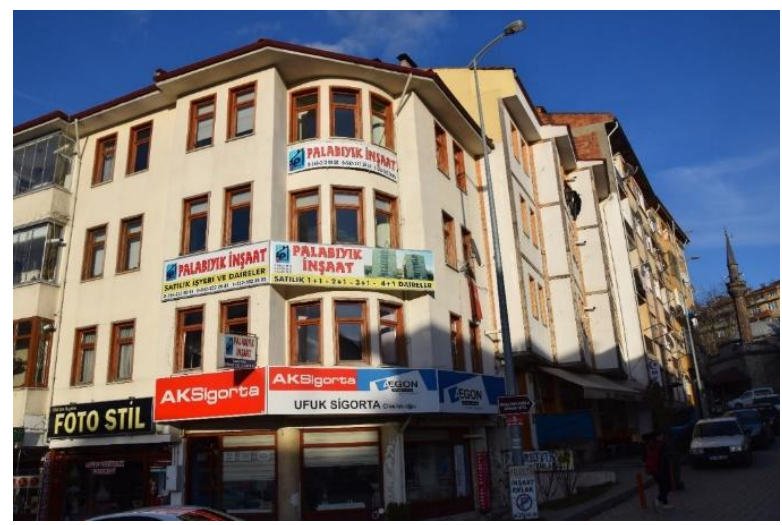

Foto 8. Zincirlioğlu Apartmanı, 2017

Bulunduğu arazinin koşullarına göre şekillenen ve kot farkından dolayı kademeli bir şekilde uzanan yapının ikinci kademesindeki dikey ve yatay ahşap şeritler geleneksel dokuya atıf içeren bir diğer unsurlardır (Foto.9). Bunun dışında yapının iç mekânında geleneksel dokuya öykünme görülmez.

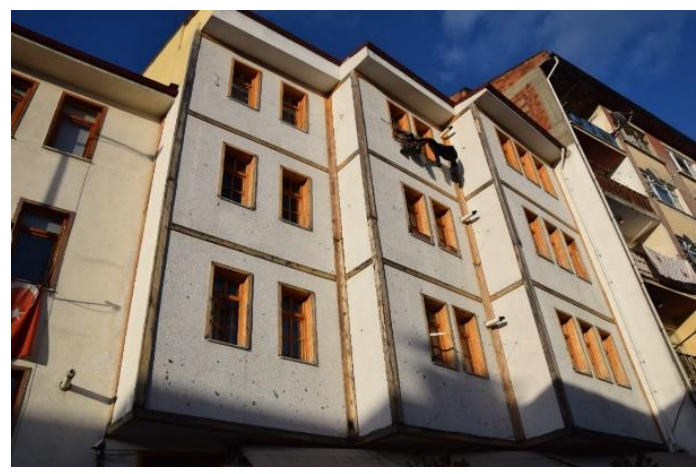

Foto 9. Zincirlioğlu Apartmanı, detay1

Sit alanı içinde inşa edilen ve Keskin apartmanına benzer bir yaklaşımı gösteren diğer bir yapı ise Hepkebirler Mahallesindeki Akikamanoğlu apartmanıdır. Betonarme karkas malzemeyle yapılan apartman üç katlı olarak inşa edilmiş ve zemin katı çeşitli işlevlerdeki dükkânlar için ayrılmıştır. İkili ve üçlü pencere düzeninin yanı sıra geniş saçaklı betonarme çatısı ve ikinci kattan itibaren yükselen çıkmalar geleneksel yaklaşımlara öykünme içerirken, yatay ve dikey ahşap şeritler geleneksel mimarinin cepheye güçlü bir şekilde taşınmasını sağlamıştır. Zincirlioğlu apartmanında geleneksel mimariye öykünme ön cephe ile sınırlı kalmıştır (Foto.10).

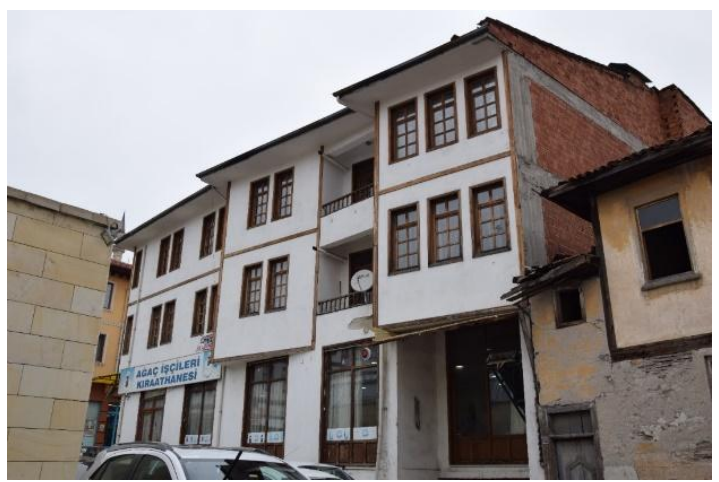

Foto 10. Alikamanoğlu Apartmanı, 2019

Sit alanı içinde inşa edilen apartmanların dışında sit alanları dışında inşa edilen apartmanlarda da geleneksel yaklaşımlar söz konusudur. Sit alanının dışında kalan apartmanlarda modern anlayışta kat 
sayılarının da arttığı görülmektedir. Geleneksel yaklaşımlar tamamen modern yapı malzemeleri ile ele alınmasına karşın bazı yapılarda geleneksel mimarinin etkileri sınırlı olsa da görülmektedir. Kuzeykent bölgesi civarında geleneksel yaklaşımla inşa edilen apartmanların sayısı diğer modern yerleşim yerlerinde inşa edilen geleneksel etkideki apartmanlara göre fazladır. Ancak çok katlı modern apartmanlarda geleneksel konut mimarisine öykünme yalnızca cephelerindeki renk dokusunda görülür. Bunun dışında bütünüyle modern mimarlık yaklaşımlarına sahip apartmanlardan hiçbir farkları yoktur. Gölpark Kuzey Kale ve Egemen Apartmanlarında çok katlı olarak inşa edilen betonarme karkas cephelerinde, katların arasında bulunan yatay şeritler ve yapının köşelerinde bulunan dikey şeritler geleneksel malzeme yerine boya ile tasarlanarak yapıya uygulanmıştır. Yapının beyaz zemini üzerinde zıtlık oluşturan bu şeritler geleneksel mimariye öykünmeyi son derece sınırlı düzeyde çizgisel bir şekilde yansıtır. İç mekânda ise geleneksel mimariye öykünme her iki yapıda da görülmez (Foto.11, 12).

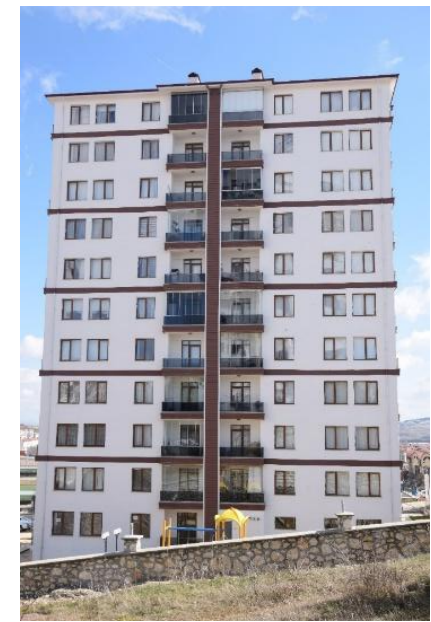

Foto 11. Gölpark Kuzey Kale Apartmanı, 2018

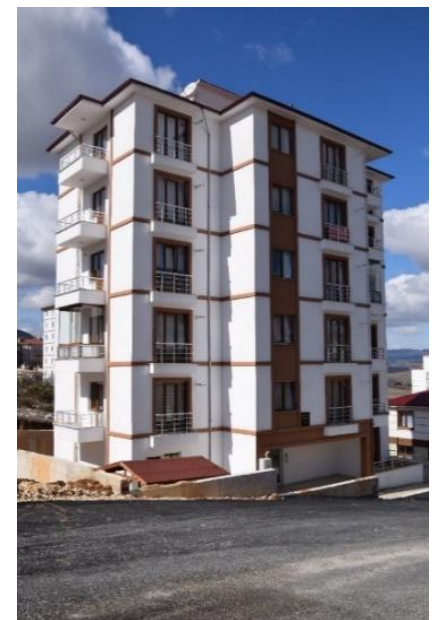

Foto 12. Egemen Apartmanı, 2018

Yine Kuzeykent'te bulunan Safran Apartmanında ise geleneksel dokuya atıf oldukça güçlüdür. Dört katlı olarak inşa edilen yapının kahverengi pimapenli pencere çerçevelerinde uygulanan renk, cephenin yatay ve dikey şeritler ile bütünlük oluşturularak geleneksel dokuya atıf yapılmıştır. Yapının ortasında iki kat boyunca yükselen çıkma biçimindeki balkonları ise geleneksel mimarideki biçimleri farklı bir yorumla ele alarak cepheyi yumuşatmıştır (Foto.13)

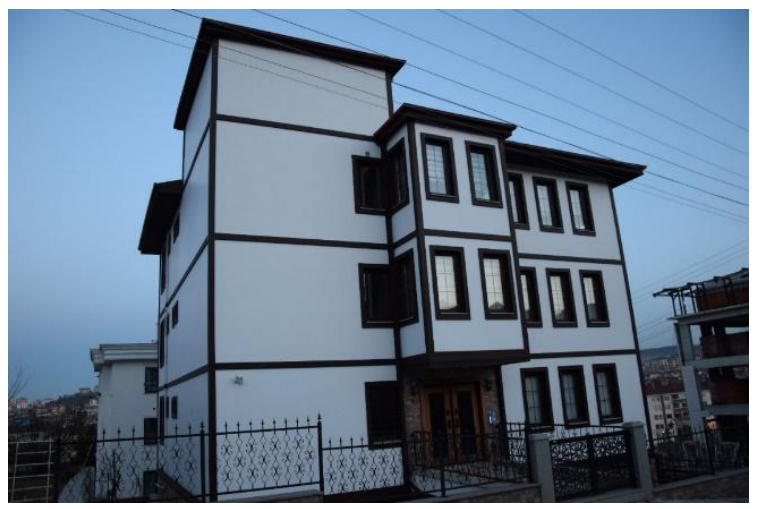

Foto 13. Safran Apartmant, ön cephe, 2017

Apartmanın ön cephesi dışında yan ve arka cephelerde de geleneksel mimariye öykünme güçlüdür. Geniş saçaklı çatısı ile bir bütünlük oluşturan renk dokusu geleneksel mimariye öykünmeyi belirginleştirmiştir (Foto.14). 


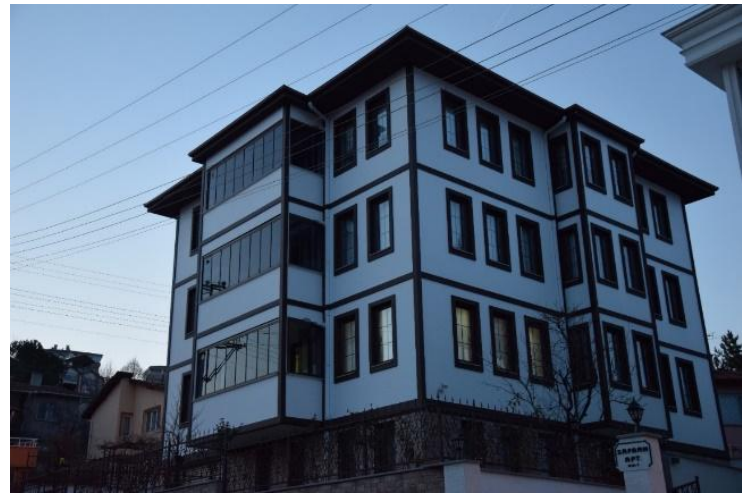

Foto 14. Safran Apartmanı, yan ve arka cephesi

\section{IV.II.Geleneksel Mimariden Etkilenerek Yaptırılan Villa Tipi Evler}

Kastamonu'da geleneksel mimariden etkilenen diğer bir yapı türüyse villa tipi sitelerde görülen yaklaşımlardır. Bu tür konutlar genellikle iki dairenin yan yana sıralanmasıyla oluşturulmuşlardır. Kentte geleneksel dokudan etkilenen villa tipi evler oldukça azdır. Kuzeykent mahallesindeki Sancak Sitesi evleri ( 2004-2008) bu tür yapı grubunda yer almaktadır. Site toplam 28 bloktan oluşmaktadır (Foto.15).

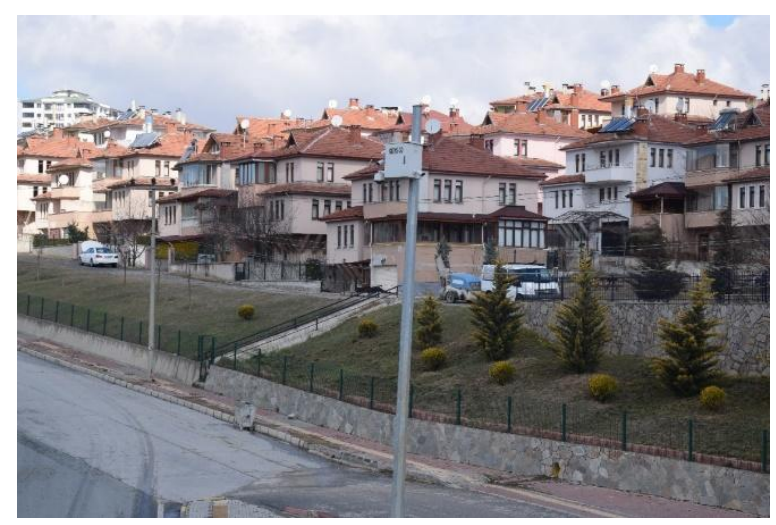

Foto 15. Sancak Sitesi, genel görünüm, 2004-2008

Sancak sitesinde bulunan villa tipi evlerde Kastamonu'nun tarihi evlerinde görülen renk dokusuna bağlı kalınmamıştır. Ancak bu sitenin her bloğunda bulunan çıkmalar ve çıkmaların altındaki betonarme destekler bazı geleneksel biçimlerin modern yapılarda uygulandığını göstermektedirler (Foto.16). Yapıların iç mekânlarında ise geleneksel mimariye öykünme yoktur.

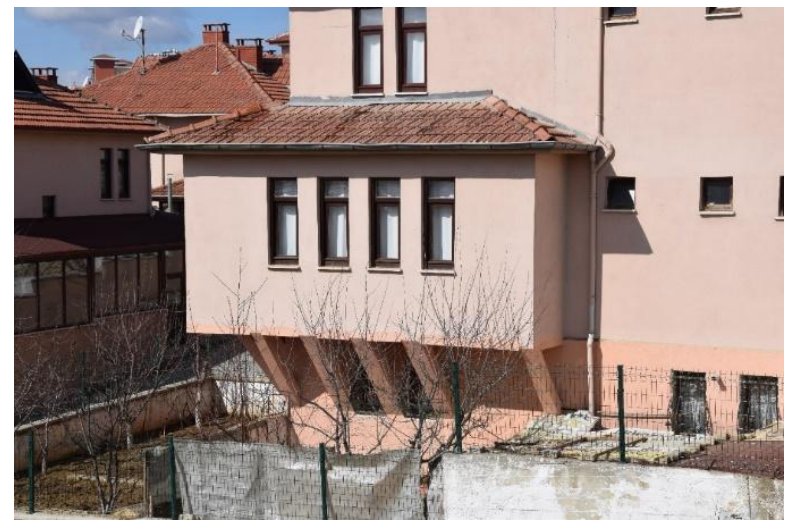

Foto 16. Sancak Sitesi, detay

\section{IV.III.Geleneksel Mimariden Etkilenen Çok Katlı Siteler}

Nüfus artışı ile genişleyen yerleşim birimlerinde barınma ihtiyacı doğrultusunda birden fazla konutu içinde toplayan yerleşim alanları ortaya çıkmıştır. Endüstri ile hız kazanan betonarme karkas yapıların 
inşas1 1950'lerden sonra Kastamonu kentinde de görülmüştür. Bu tarihlerde başta Kuzeykent olmak üzere, hız kazanan imar hareketleri bölgede yapı türlerinin de artmasına neden olmuştur. Hızlı bir şekilde gelişen Kuzeykent bölgesi 2015-2019 yılları arasında belediyenin tarihi kent dokusunu koruma projelerinden de etkilenerek geleneksel etkide yapıların inşasının artmasına neden olmuştur.

Buna karşın geleneksel dokuya öykünme oldukça sınırlı düzeyde karşımıza çıkar. Kentte geleneksel dokuya sınırlı düzeyde atıf yapılarak inşa edilen İhsangazi TOKİ Konutları (2016-2017) dışında bu anlayışa paralel proje halinde olup inşa süreçleri devam eden siteler de bulunmaktadır.

Çeşitli kentlerde yeni yerleşim birimlerinde dar bütçeli aileler için nispeten düşük bütçelerle inşa edilen TOKİ konutlarında da geleneksel mimariye ait izler görülmektedir. Bu durum daha çok yörenin mimarisi ile ilişkilidir. Kastamonu'da bu duruma benzer İhsangazi ilçesindeki TOKİ konutları dikkat çekici örnek oluşturmaktadır (Foto.17).

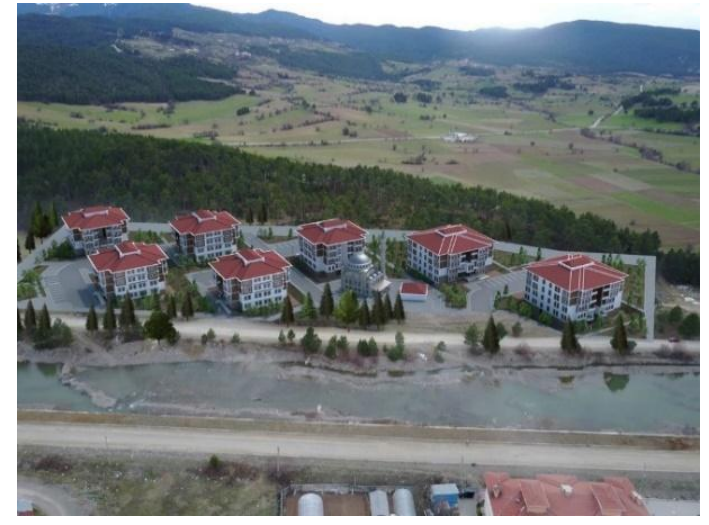

Foto 17. İhsangazi TOKİ Konut Sitesi, 2016-2017

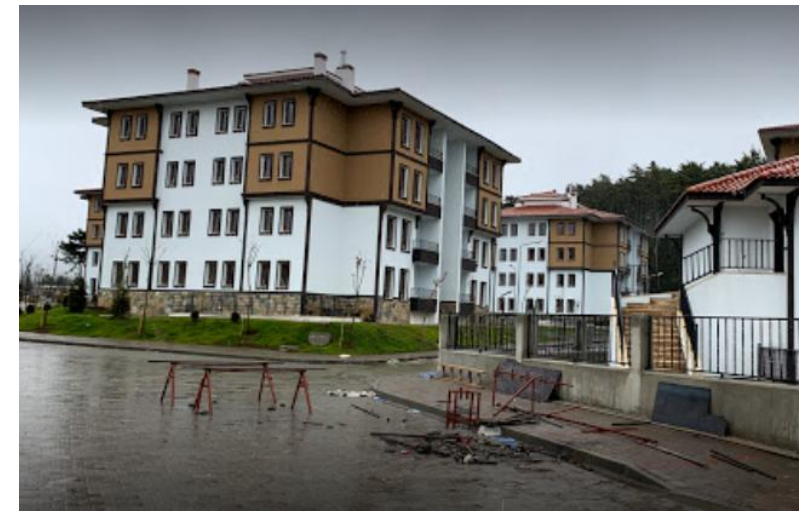

Foto 18. İhsangazi TOKI Konutlarl, detay

İhsangazi TOKİ konutları, her bir katta dört dairenin bulunduğu dörder katlı yedi binadan oluşan bir sitedir. Her blokta Kastamonu mimarisinin özelliklerinin cephelerde sınırlı düzeyde yansımaları gözlenmektedir. Bloklarda son iki katın köşeleri çıkma biçiminde kapalı balkonlar şeklinde uygulanmıștır. Çıkmaların arasındaki yatay șeritler ile yapıyı dikey yönde kesen șeritler ve ikili pencere düzeni yörenin geleneksel mimarisini yansıtmaktadırlar (Foto.18). Buna karşın blokların içinde geleneksel bir yaklaşım yoktur.

\section{V.GELENEKSEL MIMARIDEN ETKILLENEN KAMU YAPILARI İLE YARI ÖZERK VE ÖZERK KURUMLAR TARAFINDAN INSSA ETTIRILEN YAPILAR}

Kastamonu'da kamu kurumları ile yarı özerk ve özerk kurumlar tarafindan yaptırılan kamu yapıları da bulunmaktadır. Çeşitli kamusal hizmetler gerçekleştirilmesi için inşa edilen bu yapılarda geleneksel yaklaşımlar oldukça güçlüdür. Kastamonu'nun geleneksel mimarisine öykünerek inşa edilen bazı kamu yapılarına; Ketem Verem Savaş Dispanseri (2019), Atabey İmam Hatip Orta Okulu (1963) ve Adalet Sarayı (2008) örnektirler. Yarı özerk ve özerk kurumlarca yaptırılan bazı yapılara da Turizm Dayanışma Büroları (2013), Şeyh Şaban-1 Veli Kültür Vakfi binası (1996), Gazeteciler Cemiyeti (2017), El Sanatları Eğitim Merkezi (2000), Hisar Talebe Yurdu (2017), Taksi Durakları, (2019) ve Araç Otogar Binası (2017) örnek oluşturmaktadır.

\section{V.I.Geleneksel Mimariden Etkilenen Kamu Yapıları}

Kamu binaları inşa edildikleri dönemin siyasi ve sosyal politikalarının göstergesi olabilmektedirler (Oral,2019, s.613). Tanzimat ile birlikte hızlanan Osmanlı Devletindeki modernleşme aynı zamanda kamu yapıları üzerinden halka aktarılmıştır. Çeşitli amaçlara hizmet eden bu yapılar üzerinde gerçekleştirilen dönüşümler Kastamonu'da da görülen bir durum olmuştur (Yazıc1, 2007, s.12). 
Geleneksel mimariden etkilenerek inşa edilen yapılardan ilki, sit alanı içinde bulunan Ketem Verem Savaş Dispanseri'dir. 1936 tarihinde tek katlı olarak inşa edilen yapı 1970 yılında yeninden inşa edilmiştir. Bu kez iki katlı olarak inşa edilen yapı, 2000 yılında İl Sağlık Müdürlüğü hizmet binası, günümüzde ise Ketem Verem Savaş Dispanseri olarak kullanılmaktadır. ${ }^{2}$ Yapı günümüzde zemin üzerine iki katlıdır. İnşasında betonarme karkas malzemenin kullanıldığı binanın cephelerinde tarihi Kastamonu mimarisini andıran yap1 malzemesi kullanımı söz konusudur. Koyu kahve ahşap rengi ile düz lentolu sade dikdörtgen pencerelerin yapıdaki kullanımı, zemin ile birinci katı yatay biçimde kesen koyu renkteki ahşap şerit, köşelerdeki dikey şeritler, geniş saçaklı ahşap destekler üzerine oturan ahşap çatısı ile tarihi Kastamonu evlerinin cephe dokusu güçlü bir şekilde vurgulanmıştır (Foto.19).

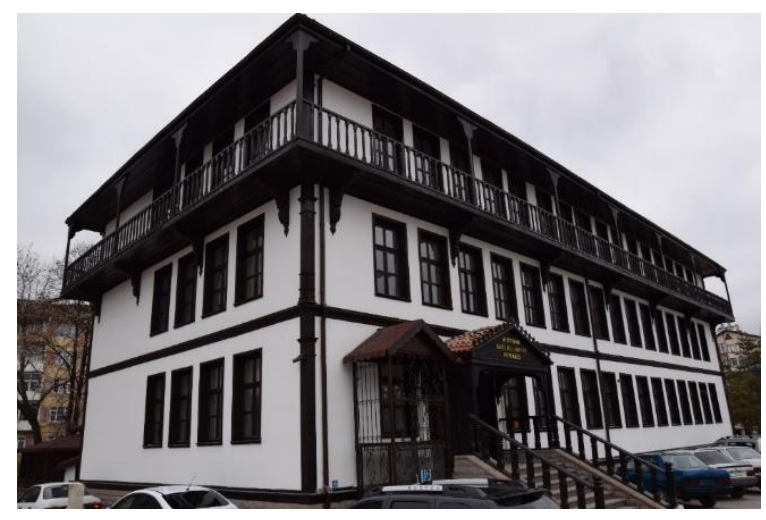

Foto 19. Ketem Verem Savaş Dispanseri, 2019

Yapının üçgen alınlıklı giriş kapısı üzerindeki kırma çatının önünde yer alan palmet motifleri ve kapının üzerindeki geometrik desenli süslemeler Selçuklu ve devamında Osmanlı sanatlarında da görülmektedir. Böylece yapıda geleneksel mimariye yönelik atıflar birden çok özellikle ele alınmıştır (Foto.20). Binanın iç mimarisinde tamamen modern yaklaşımlar görülmektedir.

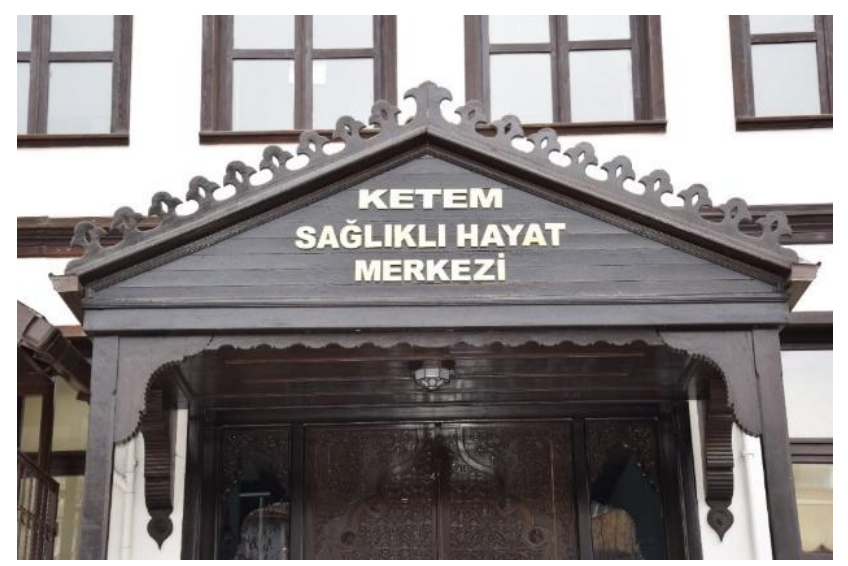

Foto 20. Ketem Verem Savaş Dispanseri, giriş kapısı detayı

Geleneksel mimariye yönelik öykünmelerin görüldüğü diğer bir kamu yapısı ise Beyçelebi mahallesindeki Atabey İmam Hatip Orta Okulu'dur. 1963 yılında inşa edilen yapı 2018 yılında büyük oranda yenilenmiştir. Bodrum katı ile birlikte dört katlı olan betonarme karkas yapının 2018 yılındaki onarımları sırasında cephelerinde dikey kahverengi boyalı şeritler içine uygulanan beyaz renk dokusu ile bölgenin mimarisine uygun bir doku elde edilmeye çalışılmıştır. Okul binası sit alanı içindeki başka kamu yapıları ile kıyaslandığında buradaki geleneksel dokunun diğer yapılara göre zayıf kaldığı gözlenmektedir. Okulun iç mekânında geleneksel mimariye öykünme yoktur.

\footnotetext{
2 İl Sağlık Müdürlüğü Arşivi, 25.03.2019
} 
25 Haziran 1992 tarihindeki 204/8 sayılı KHK kararı ile başta Adalet Sarayları olmak üzere inşa edilecek bazı kamu yapılarının çağın gelişmelerine uygun şekilde geleneksel ve modern Türk mimarisine uygun bir şekilde tasarlanacakları belirtilmektedir. ${ }^{3}$ Yine 2018 yılındaki Cumhurbaşkanlığı Seçimleri ve Genel Seçimlerdeki Beyannamelerinde Selçuklu ve Osmanlı mimarisini öne çıkaran yapıların inşasından da söz edilmektedir. ${ }^{4} \mathrm{Bu}$ kararların bir sonucu olarak bir çok ilde inşa edilen Adalet Sarayları'nda Selçuklu, Osmanlı ve bazen de yöresel mimariye öykünme bir arada görülmektedir. Kastamonu'da inşa edilen Adalet Sarayı bu bağlamda inşa edilmiştir (Foto.21).

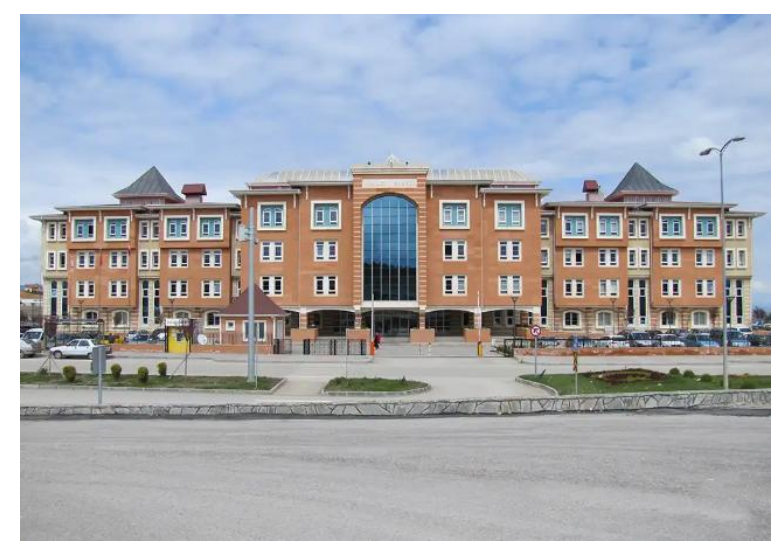

Foto 21. Kastamonu Adalet Sarayl ${ }^{5}, 2008$

Yapının cam ile kaplı yüksekçe tutulmuş giriş kapısı, Osmanlı anıtsal mimarisindeki taç kapıları anımsatmaktadır. Yine zemin katındaki cam ile kaplı giriş kapısının çevresindeki iki renkli doku Osmanlı Mimarisindeki iki renkli taş işçiliğine bir atıf içerir. Yapı genel özellikleriyle geleneksel dokuyu sadece cephelere taşırken iç mekânda böyle bir durum görülmemektedir. Cephelerinde görülen simetrik düzen, I. Ulusal Mimarlık dönemindeki seçmeci üslupla yapılan mimari eserleri andırmaktadır.

\section{V.II.Geleneksel Mimariden Etkilenen Yarı Özerk ve Özerk Kurumlarca İnşa Ettirilen Yapılar}

Kamu kurumları içinde ülkemizde yarı özerk ve özerk kurumlarca inşa edilen yapılar da bulunmaktadır. Özellikle üniversiteler, belediyeler, vakıf ve dernekler ülkemizde bu anlamda öne çıkan kuruluşlardır (Oral, 2019, s.615). Kastamonu'daki yarı özerk ve özerk kurumlarca inşa edilen yapılarda yoğun bir şekilde geleneksel mimariye öykünme görülmektedir.

Hepkebirler mahallesindeki Turizm Danışma Bürosunda iç mekân ve cephelerde oldukça güçlü bir şekilde geleneksel mimariye öykünme vardır. Nispeten küçük boyutlarda inşa edilen yapı, dışardan iki katlı bir görünüme sahip olsa da tek katlı olarak inşa edilmiştir. Büro, tamamen ahşap malzeme ile inşa edilmişken zeminde tek sıra taş kullanımı görülmektedir. Yapıya iki katlı görünüm kazandıran geleneksel mimarideki yatay şerit düşüncesi bu yapıda da görülmektedir. Dört cephesinde de görülen çıkmalar yapıda geleneksel dokuyu vurgulamak için yapılmışlardır. Pencere, kapı, renk dokusu ve geniş saçaklı çatısı ile geleneksel konut dokusuna yönelik güçlü öykünmeler içerir. Yapının yrt içi ve yurt dışından gelen turistlere danışmanlık verilmesi amacıyla yapılmasından ötürü geleneksel mimariye öykünme diğer yapılara nazaran daha güçlüdür (Foto.22).

\footnotetext{
3 Oral, 2019, s.613; "Yöresel Mimarisinin Adalet Saraylarındaki İzleri", haz., Gökçe Aras, erişim 12 Ocak, 2019, http://v3.arkitera. com/h13461-yoresel-mimarinin-adalet-saraylarindaki-izleri.htmlArkitekt.

${ }^{4}$ Cumhurbaşkanlığı Seçimleri ve Genel Seçimler Seçim Beyannamesi, Ankara: Ak Parti Genel Merkezi, erişim 10 Ocak, 2018 , s.270. http://image.yenisafak.com/resim/Beyanname23May\%C4\%B1s18_icSayfalar.pdf; Oral, 2019, s.613;

${ }^{5} \mathrm{http} / / /$ www.kastamonu.adalet.gov.tr/adliyefotogaleri.html, 20.10.2019 tarihinde erişildi.
} 


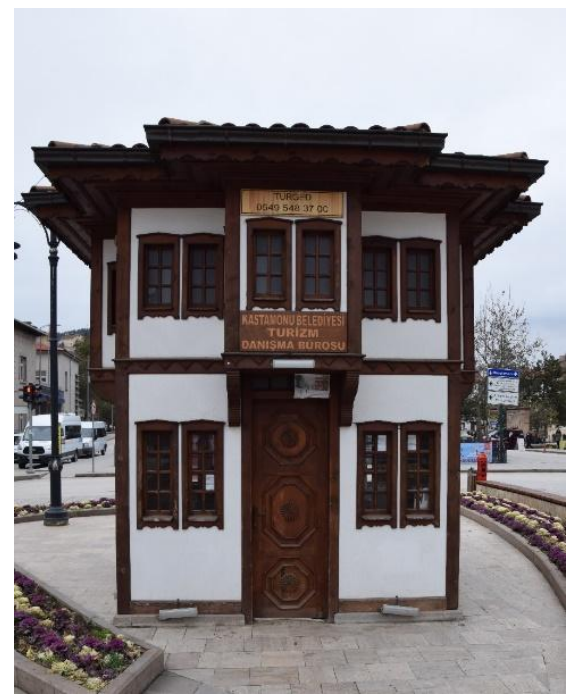

Foto 22. Turizm Danışma Bürosu, 2013

Bunun sonucu olarak cepheye hâkim geleneksel doku iç mekâna da yansımıştır. Ahşap tavanı üzerindeki ahşap tavan göbeği kare bir çerçeve içine aplike edilen bitkisel motiflerle doldurulmuştur. Bu teknikle yapılan tavan göbekleri geleneksel konut mimarisine öykünmenin iç mekândaki güçlü bir uygulamasıdır (Foto.23).

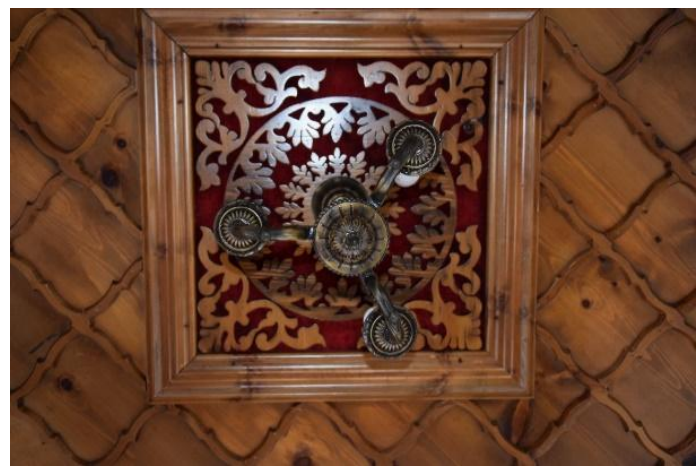

Foto 23. Turizm Danışma Bürosu, tavan göbeği

Turizm Danışma Bürosundaki iç ve dış mekâna yansıyan güçlü geleneksel dokunun bir benzeri ise El Sanatları Eğitim Merkezi Müdürlüğü binasında görülmektedir. Bu yapı Kastamonu İl Özel İdaresi ve Valiliğin sağladığı ödenekler ile 2000 yılında inşa edilmeye başlanmıştır. Ana iskeleti betonarme karkas olan yapının duvarlarında ahşap hatıllar arasına tuğla ve harç kullanımı söz konusudur. Üçgen alınlığa sahip pencere biçimleri ve ahşap şeritler ile birleşen renk dokusu ve dört cephedeki çıkmalar geleneksel mimariye öykünme içerir. İkinci katın ortasından itibaren yükselen çıkmanın ikinci bölümü geleneksel Kastamonu evlerindeki çatı odalarını andırır. Bu durum Kastamonu mimarisindeki geleneksel dokuya bağlı kalma yaklaşımlarını güçlendirmiştir (Foto.24). 


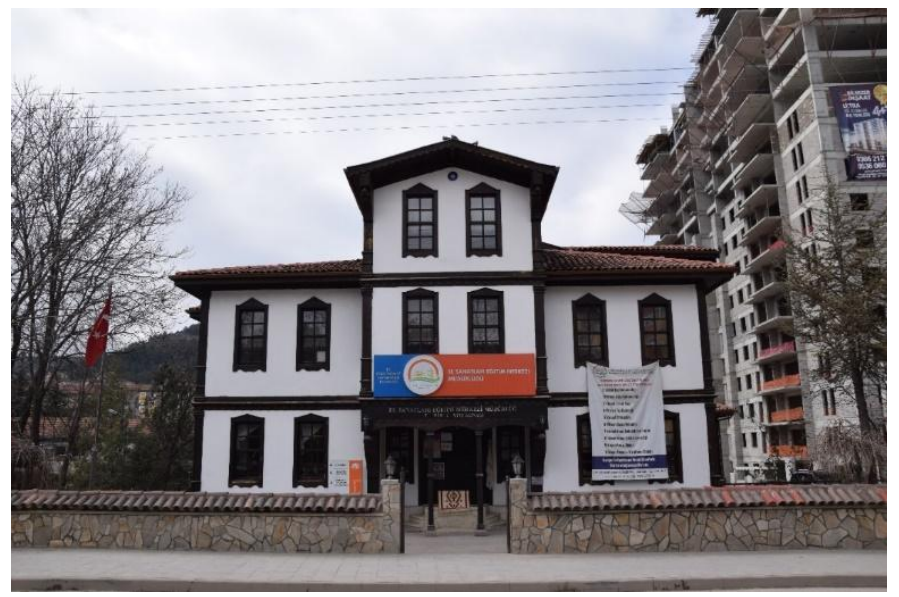

Foto 24. El Sanatları Eğitim Merkezi Müdürlüğ̈̈, 2000

İç mekânda ise geleneksel mimariye güçlü bir öykünme içerir. Ahşap tavan ve tavan göbeği süslemesi, ahşap kirişler ve iç mekândaki geleneksel günlük kullanım eşyaları yapının geleneksel dokunun yalnızca dış cephede değil yapının bütününde uygulandığını göstermesi bakımından dikkat çekicidir (Foto.25).

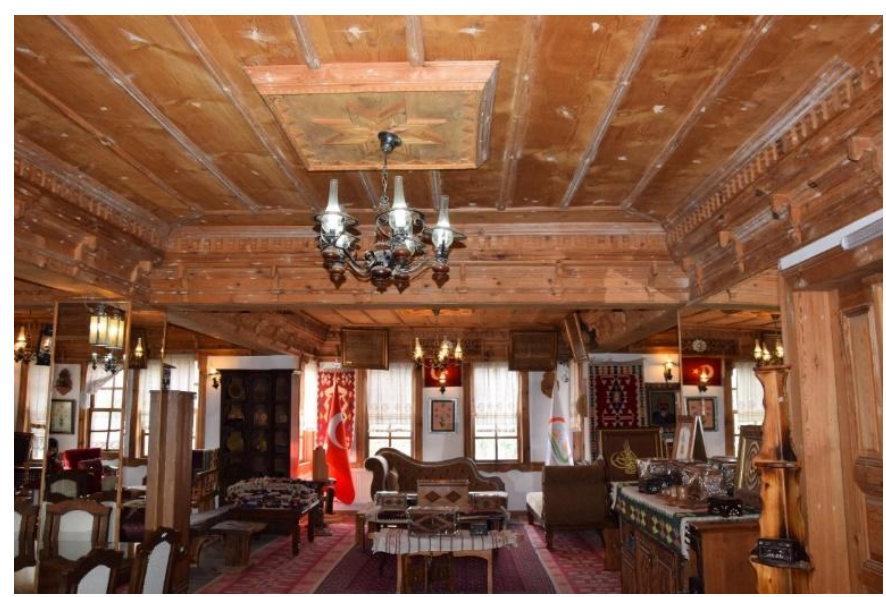

Foto 25. El Sanatları Eğitim Merkezi Müdürlügü, iç mekân

Kastamonu Belediyesine ait diğer bir yapı ise Kastamonu Gazeteciler Cemiyeti'dir. İki katlı betonarme karkas yapının cephelerindeki ahşap silmeler, pencere çerçevelerindeki renk dokusu, geniş saçaklı betonarme çatısı ve dört cephedeki çıkmalar ile tarihi Kastamonu evlerinin biçimsel özelliklerini yansıtmaktadır. Yapının iç mekân tasarımı ise tamamen modern yaklaşımlarla ele alınmıştır (Foto.26).

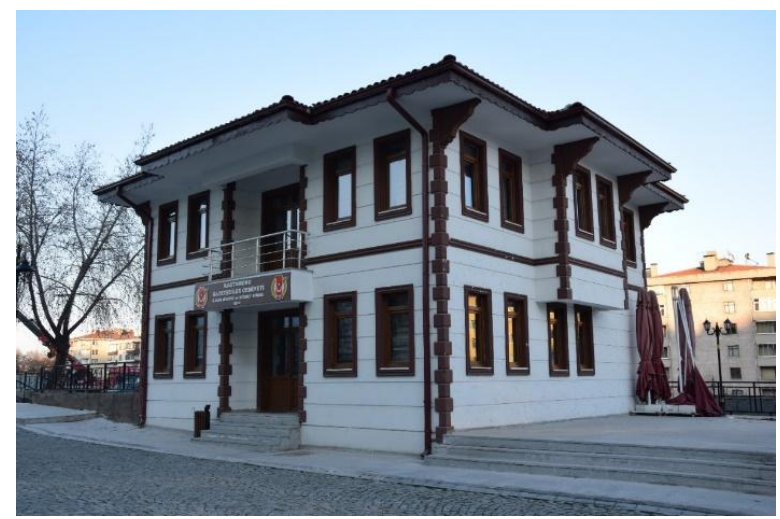

Foto 26. Gazeteciler Cemiyeti, 2017 
Kastamonu Belediyesinin kent dokusunu iyileştirme projeleri içindeki modern taksi durakları gibi yapıların tarihi dokuyu anımsatması düşüncesi ile yeni inşa edilen taksi duraklarında da geleneksel mimariye öykünme görülür. Taksi durakları, cephelerinde tasarım olarak bazı farklılıklara sahip olsalar da genel olarak tarihi kent mimarisini yansitan minimal yapılar olarak karşımıza çıkmaktadırlar (Foto.27).

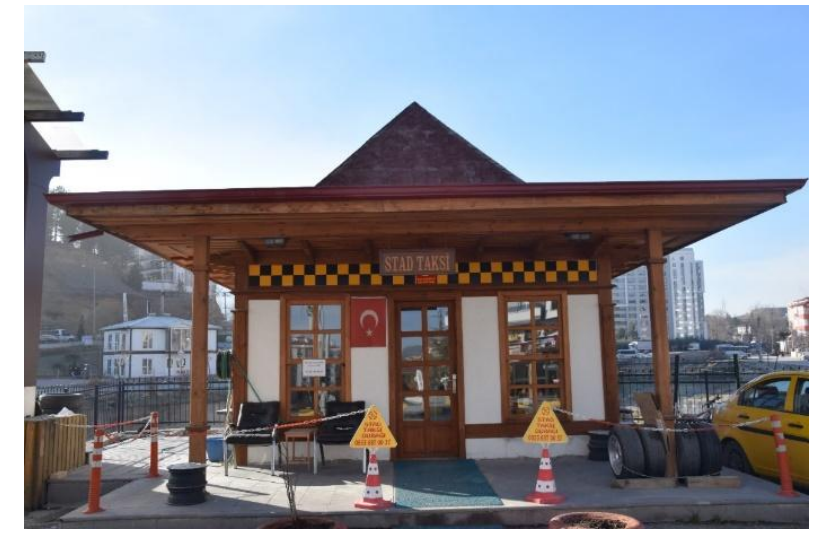

Foto 27. Stad Taksi Dură̆ 2019

Hisarardı Mahallesinde bulunan Özel Hisar Talebe Yurdu da benzer bir yaklaşıma sahiptir. Dört katlı betonarme yapının cephelerindeki çıkmalar, dikey, yatay şeritler, çatı ve çıkmaların altındaki destek öğeleri ile bütünleşen renk dokusu geleneksel mimariyi andırmaktadır (Foto.28).

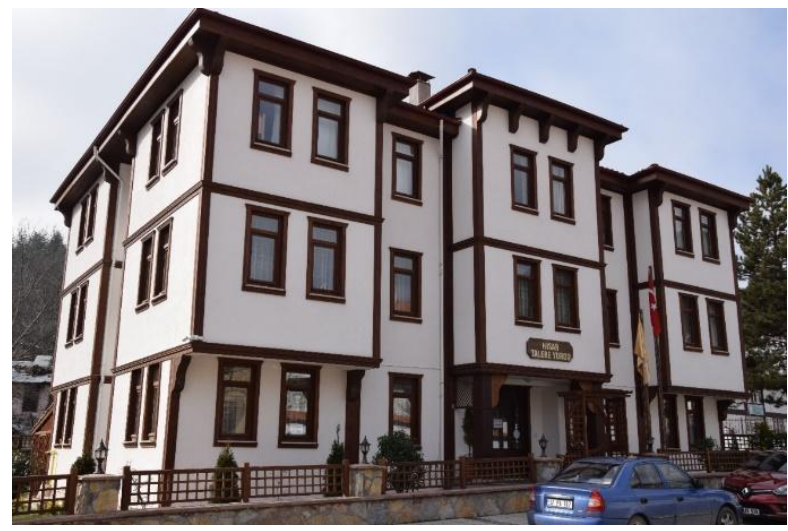

Foto 28. Hisar Talebe Yurdu, 2013-2015

\section{VI.GELENEKSEL MIMMARIDEN ETKILLENEN TÍCARET YAPILARI}

Türk mimarisinde dini ve sivil yapıların yanında kent planlarında önemli bir konuma sahip ticaret yapıları da inşa edilmiştir. Bu yapılar; hanlar, arastalar ve kapalı çarşılar dışında; modern pasajlar, iş merkezleri ve alışveriş merkezleri olarak karşımıza çıkmaktadırlar (Şahin, 2012, s.2879).

Kastamonu Osmanlı Döneminde bakır ve cevher gibi madenleri Sinop Limanı'ndan Cenevizlilere ve Venediklilere ihraç etmiştir. 1862 Yılında kente ziyarete dokumacılık ve bakırcılığın, 1884 yıllarında ise iplikçilerin varlığı belirtilmiştir. 19.yüzyıllarda ise un, arpa ve firınlardan bahsedilmiştir. 19. Yüzyılın sonlarına doğru batıdan alınan mimari formlar Kastamonu'da inşa edilen yapılara da yansımıştır. Kentteki ticaret yapılarının bir kısmında batıdan alınan biçimler öne çıkarken özellikle 2000'li tarihlerden itibaren inşa edilen bazı yapılarda geleneksel mimariye dönülmeye çalışıldığı gözlenmektedir. Çalışma kapsamında ticaret yapıları içinde Urganoğlu İş Merkezi (2015) dışında turistlerin konaklama ihtiyacını gidermek amacıyla inşa edilen Serender Otel (2004) ve Lidya Otel (2018) değerlendirilmiştir. 
2015 yılında inşa edilen Urganoğlu İş Merkezi, betonarme ve cam malzemenin yoğun kullanıldığı bir yapıdır. Dört katı olarak inşa edilen yapının ilk iki katı çeşitli iş yerleri tarafından kullanılmaktadır. Üçüncü ve dördüncü katlarında geleneksel dokuya öykünme dikey ve yatay kahverengi şeritlerde, pencere çerçevelerinde ve geniş saçaklarda görülmektedir. Orta bölüm, yanlardan daha yüksek tutulmuş ve bu bölümün çatısı geleneksel konutlardaki uygulamalara benzer şekilde ahşap desteklere oturtulmuştur. Bu uygulama taşıyıcı nitelikte olmayıp dekoratif bir uygulama olarak değerlendirilmiştir. Yapının iç mekânında ise geleneksel mimariye öykünme görülmemektedir (Foto.29).

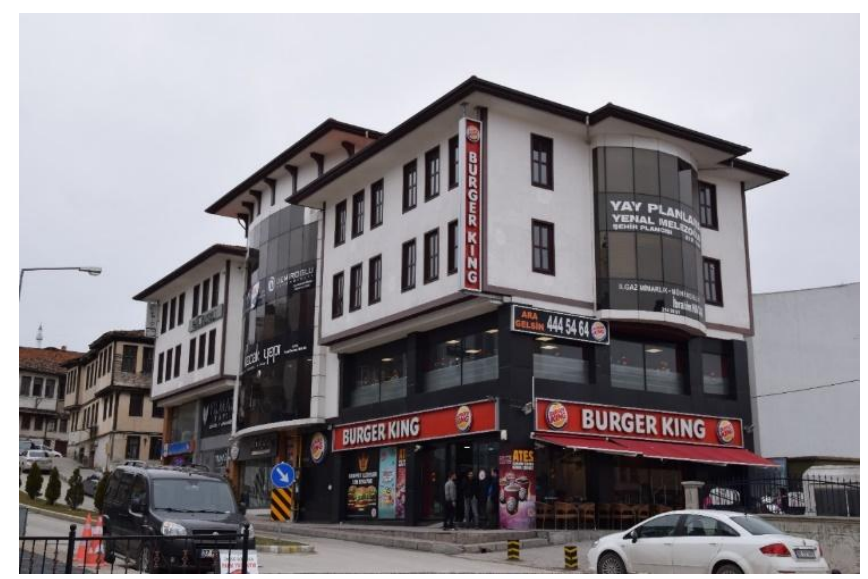

Foto 29. Urganoğlu Işs Merkezi, 2015

İş merkezleri dışında inşa edilen diğer ticaret yapıları da otellerdir. Kentte çok sayıda otel bulunmaktadır. Otellerin büyük bir bölümü orijinalde tarihi bir konak iken; restore edilerek ticari amaçla kullanılan yapılara dönüştürülmüsşür. Bunların dışında tarihi Kastamonu konaklarına öykünülerek otel olarak kullanılmak amacıyla inşa edilen modern yapılar da bulunmaktadır. Bunlardan biri 2004 yılında üç katlı olarak inşa edilen Serender Otel'dir. Otelin zemin kat giriş bölümü ahşap sütunlar üzerine oturmaktadır. Diğer kısımlarda ise taş malzeme kullanımı görülmektedir. Yapının ikinci ve üçüncü katlarında ahşap ve tuğla kullanımı görülmektedir. Bu katlarda geleneksel yapım tekniklerinin de kullanıldığı görülmektedir. Yapının ön cephesinde bulunan kırma çatılı çıkmalar geleneksel Kastamonu evlerinin bir yansımasıdır. Yapının planlanmasında modern tasarımlara bağlılık görülse de iç mekân dekorasyonunda, özellikle ahşap tavan ve süslemeleri geleneksel mimariye öykünme içerir (Foto.30).

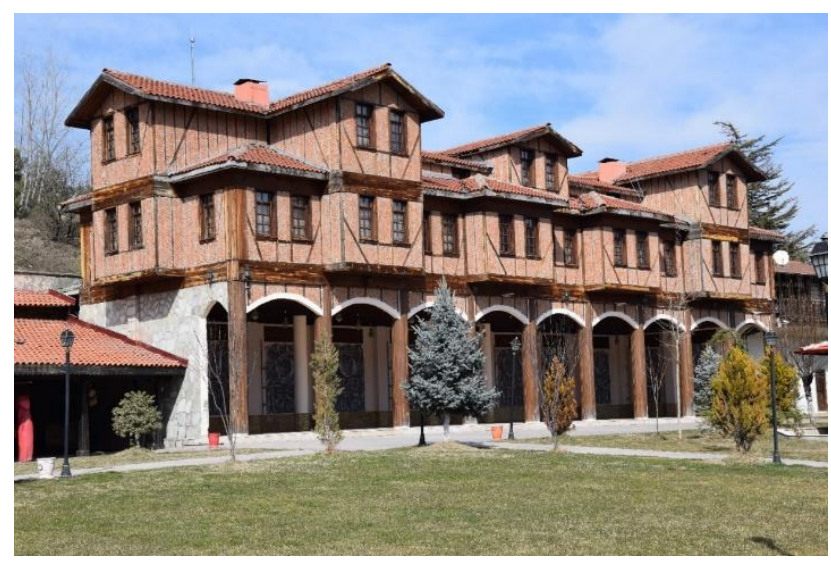

Foto 30. Serender Otel, 2004-2006

Geleneksel etkide inşa edilen diğer bir Otel ise 2018 yllında inşa edilen Lidya Oteli'dir. Betonarme karkas yapı üç katlı olarak inşa edilmiştir. Zemin kat üzerine yükselen iki kat dışa taşkın inşa edilmiştir. Dışa taşkın bu bölümleri taşıyan destekler yapının ön cephesindeki vurguyu artırmak amacıyla da yorumlanmıştır. Katlar arasındaki şeritler, pencere çevrelerindeki renk ve geniş saçağı ile yapı tarihi Kastamonu evlerinin özelliklerini yansıtır. Otelin içinde ise geleneksel mimariye öykünme yoktur (Foto.31). 


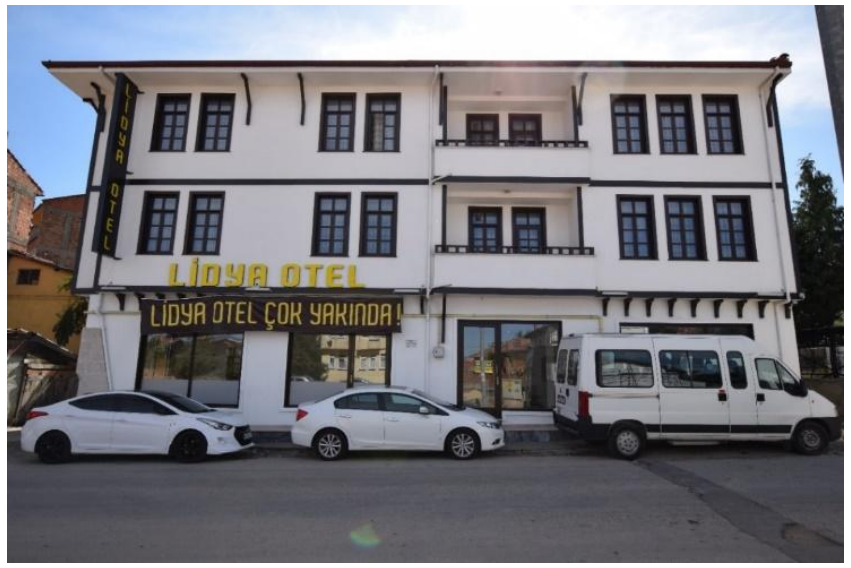

Foto 31. Lidya Otel, 2018

\section{VII.PARK, BAHÇE VE MEYDANLARDA GELENEKSEL ETKİDE YAPTIRILAN DEKORATIF ÖĞELER}

İnsanoğlunun yaşadığı çevreyi ihtiyaçları ve estetik anlayışına göre düzenlemesi çeşitli dekoratif öğelerin oluşmasına neden olmuştur. Özellikle Barok dönemden itibaren yaygınlaşan peyzaj, modern kent yaşamının önemli kıstaslarından biri olmuştur. Böylece günümüz kent yaşamında peyzaj düzenlemeleri nispeten daha görünürdür. Kastamonu kentinde de belediye tarafindan yapılan bazı dekoratif öğeler kentin farklı yerlerinde konumlandırılmışlardır.

$\mathrm{Bu}$ dekoratif işlevsel belediye çöp konteynırları farklı bir uygulama ile ele almıştır. Yerin belli bir derinliğine kadar kazılmasıyla elde edilen çöp toplama yerlerinin hemen üstü tarihi evlerin birer minyatür biçimindeki uygulaması şeklinde yapılmışıı. Bu örnek, tarihi dokunun etkilerinin çevre düzenlemelerinde çok farklı noktalarda nasıl ortaya çıkabileceğini göstermesi bakımından dikkat çekicidir (Foto.32).

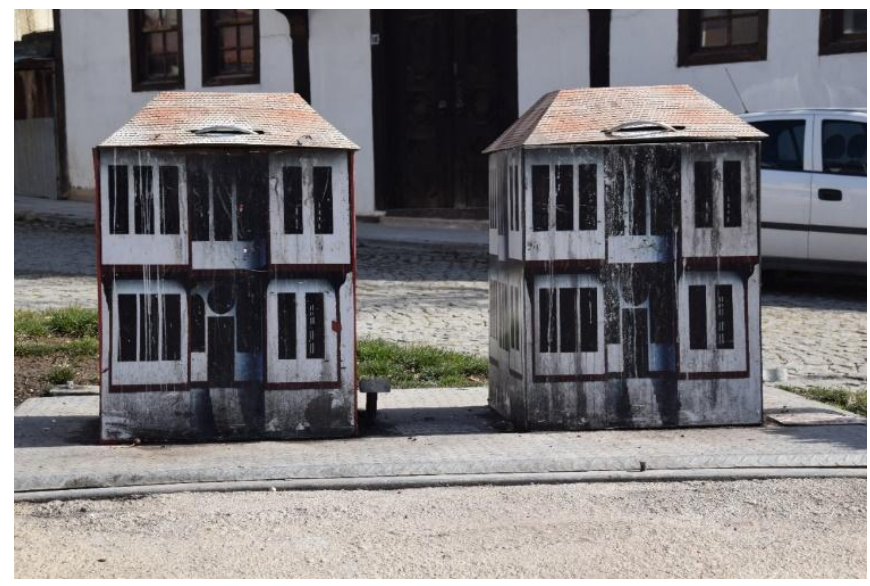

Foto 32. Çöp Kutulart

Bir diğer uygulama da sokak kütüphaneleridir. Sokak kütüphaneleri özellikle şehrin açık park ve bahçelerinde belediyenin insanların dinlenmesi için koyduğu bankların yakınına konumlandırılan ahşap görünümündeki metal bir direk üzerine yapılmış kitaplıklardır. Bu kitaplıklar yine tarihi Kastamonu evlerine öykünülerek tasarlanmışlardır (Foto.33) 


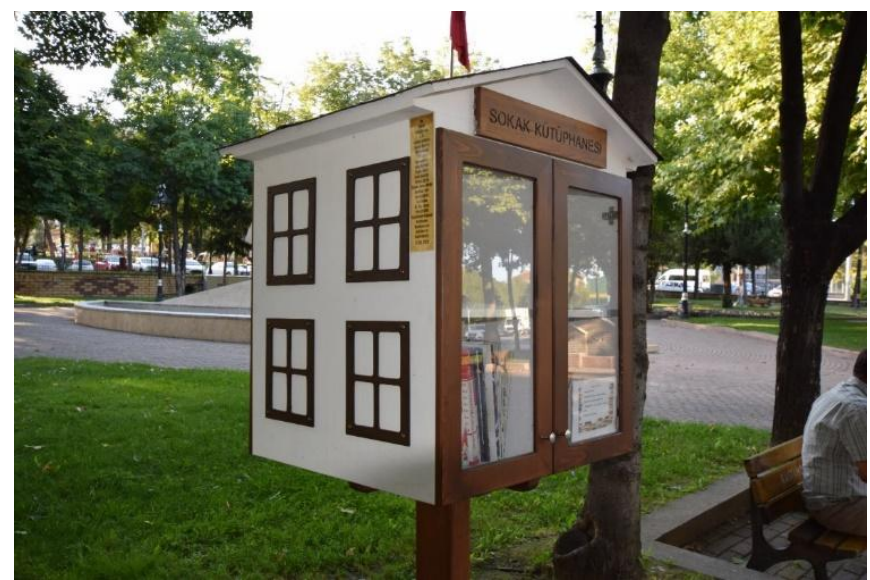

Foto 33. Sokak Kütüphanesi

Sokak kütüphanesi gibi tasarlanan diğer bir dekoratif öğe ise parkların içinde bulunan kuş evleridir. Yüksek tutulan demir direk üzerinde aynı malzemeden dekoratif kuş evleri yapılmıştır. Bu evler üçgen alınlıkları ve renk dokusu ile kentin tarihi mimarisini yansıtmaktadırlar (Foto.34).

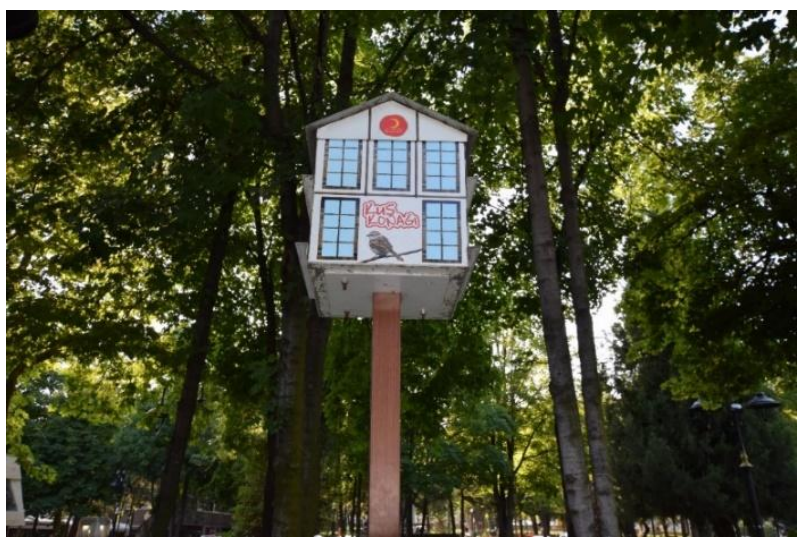

Foto 34. Kuş Evi

\section{SONUÇ}

Kastamonu, tarihi ve modern yerleşimin bir arada görüldüğü kentlerden biridir. Kentte geleneksel mimariye öykünülerek inşa edilen yapılar görülmektedir. Kent içindeki tarihi yapıların korunması ile birlikte hem kültürel geçmişe sahip çıkılmaya hem de kentin turizm potansiyeli canlandırılmaya çalışılmıştır. Bunun kentteki ilk yansıması geleneksel dokuya öykünülerek inşa edilen modern sivil yapılarda görülür. Kastamonu Belediyesi’nin ortaya koyduğu projeler, bu durumu destekler nitelikte kentin geleneksel ve modern mimarisi arasındaki ilişkiyi güçlendirmiştir. Bu koruma uygulamaları neticesinde Kastamonu, Kazakistan'daki 2018 yılın Türk Kültürü Teşkilatı Daimi Konseyi’nde Türk Dünyası Kültür Başkenti seçilmiştir. Böylelikle kentteki tarihi dokunun korunması hususunda hassasiyetler artmıştır.

Geleneksel mimariye öykünülerek inşa edilen yapılarda seçmeci anlayışta uygulamalar görülmektedir. Geleneksel mimariye bağlı gerçekleştirilen yapılar geçmiş ile kurulan bağın geleceğe aktarılması amacından doğmuştur. Kastamonu kentindeki geleneksel dokuya öykünme düşüncesi çoğunlukla apartman tarzı yapılar üzerinde yoğunlaşmıştır. Sit alanı içinde inşa edilen apartmanlarda geleneksel yaklaşım yeni şehir merkezindeki apartmanlara göre daha yoğundur. İki farklı yerleşim yerindeki apartmanlarda bu tür bir farklılığın ortaya çıkması sit alanları içindeki yapıların bulundukları dokuya bağlı kalması ve çoğunlukla kentsel koruma uygulamalarından dolayıdır. Her iki bölgedeki apartmanlarda da tarihi Kastamonu evlerinin çizgisel özellikleri görülürken sit alanı içindeki apartmanlarda bazı geleneksel biçimler de gözlemlenmektedir. Kent merkezinde geleneksel dokuya atıf yapan apartmanların varlığı ilçelere taşınmamıştır. İlçelerde apartmanlar üzerinden geleneksel mimariye öykünme içeren yapılar oldukça sınırlı sayıdadır. Çok katlı siteler üzerinden geleneksel evlere benzer 
yaklaşımlar daha çok TOKİ konutlarının oluşturdukları sitelerde görülürken, kişilere ait sitelerde geleneksel mimariye öykünme kaygısı zayıftır. Özel teşebbüslerin yaptırdığı tarihi Kastamonu evlerine bağlı inşa edilen yapılar yalnızca sit alanlarının dışında görülmektedirler. Kentte villa tipi evlerde bu durum oldukça azdır. Ancak Kuzeykent'te bulunan Sancak sitesi evlerinde geleneksel mimariye öykünme belirgindir. Sit alanı içinde ise modern yapı malzemeleri ile inşa edilen villa tipi evlere rastlanmaz. Bu tür yapılar Cide, Pınarbaşı, İnebolu gibi ilçelerde olmalarına rağmen yapılarda geleneksel yaklaşımlar görülmemektedir.

Konutlar dışında kamu yapıları ve yarı özerk ile özerk kurumlar tarafından inşa edilen yapılarda tarihi dokuya öykünme oldukça güçlüdür. Sit alanı içinde bulunan kamu yapılarında kentin tarihi dokusuna yönelik uygulamalar evlerin özellikleri sadece cephelerde, bazı geleneksel biçimler ve çizgisel özellikler üzerinden görülürken sit alanı dışındaki kamu yapılarında bu etki zayıftır. Sit alanı içinde belediye tarafından inşa edilen yapıların bazılarında cephelerin yanı sıra iç mekânlarda da geleneksel özellikler görülmektedir. Sit alanı dışındaki yapılarda bu etki sadece cephelerde görülmektedir. Ticaret yapılarında geleneksel dokuya öykünme sadece sit alanı içindeki yapılar üzerinden yapılmış olsa da bu öykünme diğer yapı türlerine göre oldukça zayıf kalmıştır.

Kentin peyzaj düzenlemelerinde geleneksel etkide yaptırılan dekoratif öğelerin sayısı ise oldukça azdır. Genel olarak bütün yapı türleri ele alındığında ise geleneksel etkinin sit alanından uzaklaştıkça zayıfladığı gözlenmektedir. Son dönemlerde belediyenin de projeleri içinde yer alan geleneksel etkideki konutlar yapma projesi olsa da bu düşünce sadece yapıların cephe kaplamaları ile sınırlıdır. Aslında sit alanları dışında tarihi dokunun kopya edilmesinin de mimarlık tarihi açısından sorunlu olduğunu söylemek gerekir.

Sit alanı içinde inşa edilen modern yapıların geleneksel konut dokusuna uygun olarak inşa edilmeleri ya da onarımlarının gerçekleştirilmesi, Kültür ve Turizm Bakanlığı'nın Koruma Amaçlı İmar Planları ve Çevre Düzenleme ${ }^{6}$ yönetmeliğinin esaslarına göre hukuki bir zorunluluktur. Ancak sit alanı dışındaki geleneksel dokuya uyma çalışmaları kanunen belirli bir zorunluluk içermemektedir. Bu durum sit alanı dışında inşa edilen yapılarda geleneksel dokunun daha zayıf olmasının başlıca nedenidir.

Kastamonu'da ilin geneline yayılan tarihi konak ve evler bulunmasına rağmen geleneksel dokuya öykünme çabaları kent merkezinde yoğunlaşan bir durum olmuştur. Özellikle İnebolu, Azdavay, Araç, Pınarbaşı, Küre, Abana ve Bozkurt gibi ilçelerde tarihi konakların olmasına karşın bu yerlerde geleneksel dokuya atıf birkaç yapı ile sınırlı kalmıştır. Kastamonu dışında Batı Karadeniz Bölgesindeki diğer illerde de benzer adımlar atılmıştır. Bunların başında Karabük iline bağlı Safranbolu ilçesi gelmektedir. UNESCO Dünya Miras Kenti olan Safranbolu'da özellikle son yirmi yıl içinde inşa edilen yapılarda geleneksel dokuya öykünmede nicel olarak artış görülür (Oral, 2019, 597-631). Safranbolu'daki bu yaklaşım Kastamonu'ya da örneklik oluşturmuştur.

Ayn1 yıl Uluslararas1 Anttlar ve Sitler Konseyi Türkiye Milli Komitesi'nin (ICOMOS) kentte gerçekleştirdiği toplantıda; Kastamonu'nun koruma politikalar konusunda son y1llarda önemli gelişmeler gösterdiğine değinilmiştir. ${ }^{7} \mathrm{Bu}$ durum, son yıllarda artış gösteren tarihi dokuya bağ lilığın bir sonucudur. Bunun sonucunda turizm alanında da kaydedeğer olumlu gelişmeler görülmeye başlanmıştır. Benzer şekilde kültürel değerlerin korunduğu birçok kent ülkemizde bulunmaktadır. Örneğin Amasya'da geleneksel dokuya öykünme Safranbolu ve Kastamonu illeri kadar yoğun olmasa da benzer yaklaşımlarla ele alınan yapılara, kentin farklı yerlerinde karşılaşmak mümkündür. Bunun dışında Şirince, Uşak, Bergama, Gönyük, Mudurnu gibi yerleşim yerlerinde de tarihi dokuya öykünülerek inşa edilen tekil örnek oluşturabilecek yapılar görülebilmektedir. Ayrıca Bolu kenti özelinde yapılan bir araştırmada, Alpagut "modern konutlarda geleneksel olandan vazgeçilmediğini belirterek bu durumu 'Türk'e Özgü' olarak” ifade etmiştir (2018, s.115).

Sonuç olarak Kastamonu kentinin sit alanı içindeki ve sit alanı dışındaki yerleşim yerlerinde geleneksel konut mimarisine öykünülerek inşa edilen yapılarda nicel olarak önemli bir artış olduğu belirlenmiştir. Kisa ve orta vadede bu durumun devam edeceğini de öngörmek mümkündür.

\footnotetext{
${ }^{6}$ Koruma Amaçlı İmar Planları ve Çevre Düzenleme Projelerinin Hazırlanması, Gösterimi, Uygulaması, Denetimi ve Müelliflerine İlişkin Usul ve Esaslarına Ait Yönetmelik, 2005.

${ }^{7}$ Kastamonu Belediyesi Resmi Web Sitesi: Kastamonu.bel.tr/v2/ 08.10.2019 tarihinde erişildi.
} 
Bilgilendirme / Acknowledgement: Bu çalışma, Karabük Üniversitesi Bilimsel Araştırma ve Proje Birimi (BAP) tarafından desteklenen, yürütücülüğünü ve danışmanlığını Dr. Öğr. Üyesi Bülent ORAL'ın yaptığı SYL2019-2023 kodlu proje ve aynı adlı yüksek lisans tezinden yararlanılarak üretilmiştir / This study was provided by the Scientific Research and Project Unit (BAP) of Karabuk University. It was produced by using the project coded SYL2019-2023 and the same master's thesis, which is carried out under the direction and consultancy of Asst. Prof. Dr. Bülent ORAL.

\section{KAYNAKÇA}

Alpagut, L. (2018). Bolu'da erken Cumhuriyet dönemi sonrası konut: Kopuşlar ve süreklilikler. Ç.Ü. Sosyal Bilimler Enstitüsü Dergisi, 24(1), 109-122.

Aras, G. (2019). Yöresel mimarinin adalet saraylarındaki izleri. 1 Mayıs 2019 tarihinde $\mathrm{http} / / / \mathrm{v} 3$.arkitera.com/h13461-yoresel-mimarinin-adalet-saraylarindaki-izleri.htmlArkitekt adresinden erişildi.

Aslanoğlu, İ. (1980). Erken Cumhuriyet dönemi mimarlı̆̆ı. Ankara: ODTÜ Mimarlık Fakültesi Basım İşliği.

Bridge, N. (2018). Mimarlık 101. (Çev. Funda Sezer). İstanbul: Say Yayınları.

Cumhurbaşkanlığı seçimleri ve genel seçimler seçim beyannamesi. Ankara: Ak Parti Genel Merkezi, s. 270. 10 Ocak 2018 tarihinde http:image.yenişafak.com/resim/Beyanname adresinden erişildi.

Çolpan, N. ve Biçer, E. (2002). Kastamonu örneğinde Anadolu kenti imaj örnekleri ve değişim süreci. Yayınlanmamış doktora tezi. İstanbul: Yıldız Teknik Üniversitesi, Fen Bilimleri Enstitüsü, Şehir ve Bölge Planlama Anabilim Dalı, İstanbul.

Eldem, S. H. (1984). Türk evi. İstanbul: TAÇ Vakfi Yayınları.

Eyüpgiller, K.K. (1999). Bir kent tarihi Kastamonu. İstanbul: Eren Yayınc1lık.

Frampton, K. (2007). Modern architecture, Critical History. London: Thames Hudson.

Gökoğlu, A. (1952). Paphlagonia/Paflagonya Kastamonu, Sinop, Çankırı, Bartın, Bolu, gayri menkul eski eserleri ve arkeolojisi. Kastamonu: Doğrugöz Matbaası.

Günay, R. (1998). Türk ev geleneği ve Safranbolu evleri, İstanbul: Yapı Endüstri Merkezi Yayınları.

$\begin{array}{llllll}\text { Kastamonu } & \text { adalet } & \text { saray1. } & 20 & \text { Eylül } & 2019\end{array}$ http://www.kastamonu.adalet.gov.tr/adliyefotogaleri.html adresinden erişildi.

Kankal, A. (2004). Türkmen kaidesi Kastamonu (XV-XVIII. yüzyıllar arası şehir hayatı). Ankara: Zafer Matbaa.

Oral, B. (2019). Geleneksel mimariye öykünme bağlamında günümüz Safranbolu sivil mimarisi. İnsan ve Insan, 21, 597-631.

Özlü, N. (2015). Türk mimarisinde iz bırakanlar 1, Alexandre Vallaury. Ankara: Afşar Matbaac1lık.

Şahin, F. (2012). Ticaret yapılarında tarihsel gelişim ve tipolojiler; Trabzon üzerine yansıyış şekilleri. Tarih ve Medeniyetler Tarihi, 4, 2879-2894.

Şahin, İ. (2001). Kastamonu. TDV İslâm Ansiklopedisi (DİA) içinde (c. 24, ss.58). İstanbul: Diyanet Vakfi Yayınları.

Uzunçarş111, İ. H. (1988). Anadolu beylikleri ve Akkoyunlu, Karakoyunlu beylikleri. Ankara: Türk Dil Kurumu Yayınları. 
Yazıcı, N. (2007). Osmanlılarda mimarlık kurumunun evrimi ve Tanzimat dönemi mimarlık ortamı. Yayımlanmamış doktora tezi, İstanbul: Mimar Sinan Güzel Sanatlar Üniversitesi Sosyal Bilimler Enstitüsü.

Yeter, E. (2002). Türkiye'de tarihi kent dokularının korunmasında valiliklerin önemi. Türkiye'de Tarihi Kent Dokularının Korunması ve Geleceğe Taşınması Sempozyumu. Ankara: Kültür ve Tabiat Varlıklarını Koruma Genel Müdürlüğü. 